\title{
Paleoseismological evidence of Holocene activity of the Los Tollos Fault (Murcia, SE Spain): A lately formed Quaternary tectonic feature of the Eastern Betic Shear Zone
}

\author{
J.M. Insua-Arévalo1* , J. García-Mayordomo², A. Salazar², E. Rodríguez-Escudero³, R. Martín- \\ ${\text { Banda }{ }^{1,2}, \text { J.A. Álvarez-Gómez }}^{1}$, C. Canora ${ }^{4}$, J.J. Martínez-Díaz ${ }^{1,5}$ \\ ${ }^{1}$ Department of Geodynamics, Faculty of Geological Sciences, Complutense University of Madrid, 28040 Madrid, Spain. \\ ${ }^{2}$ Instituto Geológico y Minero de España (IGME), c. Ríos Rosas, 23. 28003 Madrid, Spain. \\ ${ }^{3}$ Department of Geology, Universidad Autónoma de Madrid, 28049 Madrid, Spain. \\ ${ }^{4}$ Instituto Superior Técnico de Lisboa, Departamento de Sismología, Av. Rovisco Pais 1, 1049-001 Lisboa, Portugal \\ ${ }^{5}$ Geosciences Institute IGEO (UCM, CSIC), c. José Antonio Nováis, 12, 28040 Madrid, Spain.
}

e-mail addresses: insuarev@ucm.es (J.M.I-A.*Correspondingauthor),julian.garcia@igme.es (J.G-M.), a.salazar@igme.es (A.S.),emilio. rodriguez@uam.es (E.R-E.) raqueliensse@hotmail.com (R.M-B.),jaalvare@ucm.es (J.A.A-G.), ccanora@ucm.es (C.C.),jmdiaz@ucm.es (J.J.M-D.)

Received: 24 September 2015 / Accepted: 20 November 2015 / Available online: 20 December 2015

\begin{abstract}
The Los Tollos Fault is a recent and important feature of the Eastern Betic Shear Zone, one of the major tectonic structures in South Iberia accommodating the convergence between Nubian and Eurasian plates in the western Mediterranean. The Los Tollos Fault became active by the end of Middle Pleistocene introducing some paleogeographical modifications. Previously mapped as a secondary normal fault related to the Carrascoy Fault, recent research evidences that the Los Tollos Fault is an independent Holocene active left-lateral reverse fault extending for at least $15 \mathrm{~km}$. Data analysis from 4 trenches dug across the fault has revealed the occurrence of at least two paleo-earthquake events during the Holocene. The most recent event is dated between 2,740 and 2,140 yr BP (8th to 2nd centuries BC). The size of the paleoevents is calculated to be Mw $6.3-6.6$ following empirical regressions on surface rupture length. The recurrence interval is estimated to be between 2,200-6,860 years, fitting a slip rate for the fault between 0.12 and $0.17 \mathrm{~mm} / \mathrm{yr}$. Such parameters highlight the Los Tollos Fault as a tectonic structure with a considerable activity located relatively close to densely populated areas. These seismogenic parameters should be considered in future reassessments of the seismic hazard of the region.
\end{abstract}

Keywords: Paleoseismology, active faults, Betic Cordillera, Los Tollos Fault, Eastern Betic Shear Zone (EBSZ)

\section{Resumen}

La falla de Los Tollos es una estructura reciente e importante de la Zona de Cizalla de la Bética Oriental, la principal estructura del sureste de la Península Ibérica que acomoda gran parte de la convergencia entre las placas de Eurasia y Nubia en el Mediterráneo Occidental. La falla de Los Tollos, descrita inicialmente como una falla normal secundaria relacionada con la falla de Carrascoy, comenzó su actividad a finales del Pleistoceno Medio generando algunas modificaciones paleogeográficas significativas. El trabajo que aquí presentamos demuestra su activad durante el Holoceno con una cinemática lateral sinestral con componente inversa a lo largo de una longitud de $15 \mathrm{~km}$, e independiente de la Falla de Carrascoy. Del análisis de los datos obtenidos en 4 trincheras paleosismológicas realizadas a lo largo de la traza de la falla, se han podido interpretar la ocurrencia de al menos 2 paleoterremotos durante el Holoceno, acotándose el evento más reciente entre hace 2.740 y 2.140 años (siglos VIII a II a.C.). La magnitud máxima de estos paleoterremotos, estimada mediante correlaciones empíricas que consideran la longitud de rotura en superficie de la falla, se encuentra entre Mw 6,3 y 6,6, con un periodo de recurrencia comprendido entre 2.200 y 6.860 años. La tasa de deslizamiento neta calculada para la falla se estima entre 0,12 y 0,17 mm/a. Estos parámetros identifican la falla de Los Tollos como una estructura activa situada en las cercanías de áreas densamente pobladas y ponen de manifiesto el interés que tendría considerarla en futuras reevaluaciones de la peligrosidad sísmica en la región. 


\section{Introduction}

The NW-SE convergence between the Nubian and Eurasian plates in the western Mediterranean (4-5 mm/yr) (e.g., DeMets et al., 1990; McClusky et al. 2003; Serpelloni et al., 2007; Nocquet, 2012) produces a crustal deformation of the southeastern Iberian Peninsula where Late Neogene and Quaternary faulting activity is dominated by a large NESW left-lateral, strike-slip fault system known as the Eastern Betic Shear Zone (EBSZ) (De Larouzière et al., 1988; Silva et al., 1993) (Fig. 1). The EBSZ is a cortical structure (Banda and Ansorge, 1980) in NNE to NE direction with a sigmoidal trace that stretches for more than $450 \mathrm{~km}$. It includes, from north to south, the Bajo Segura Fault (BSF), the Carrascoy Fault (CAF), the Alhama de Murcia Fault (AMF), the Palomares Fault (PF), and the Carboneras Fault (CF) (e.g. Bousquet, 1979; Silva et al., 1993).

Historically, several of the most destructive earthquakes in the Iberian Peninsula, reaching intensities up to $I_{E M S 98} \mathrm{IX}-\mathrm{X}$, have occurred in the area (IGN, 2013). These events have been related to the main faults belonging to the EBSZ: the $1518 \mathrm{AD}$ Vera (VII-IX) earthquake to the PF (Silva et al., 2003; García-Mayordomo, 2005), the 1522 AD Almería (IX) event to the CF (Gràcia et al., 2006; Reicherter and Hübscher, 2007), and the 1829 AD Torrevieja (IX-X) earthquake to the BSF (Alfaro et al., 2002, 2012; García-Mayordomo and Martínez-Díaz, 2006; Perea et al., 2012). Recently, one of the most damaging earthquakes occurring during the instrumental period, the Lorca earthquake (11/05/2011, $\mathrm{M}_{\mathrm{w}} 5.2$, $I_{\text {EMS98 }}$ VII), has been related to the AMF (e.g.: Vissers and Meijninger, 2011; Martínez-Díaz et al., 2012a).

The Los Tollos Fault (LTF) is located close to densely populated villages (e.g. Alhama de Murcia, Totana, Fig. 2) and is less than $30 \mathrm{~km}$ away from the city of Murcia, with almost half a million inhabitants. This situation confers to the study of the seismogenic potential of the LTF considerable importance for the appropriate management of the local seismic hazard and risk. For this reason the aim of this work is to contribute new data to parameterize the paleoseismicity of this active fault in order to be included in future seismic hazard assessments of the region (García-Mayordomo et al., $2007 \mathrm{a}, \mathrm{b}, \mathrm{c})$. We have estimated the date of the last surfacerupture earthquake, the mean recurrence interval between maximum events, and the fault slip rate.

The LTF has been mapped previously as a normal fault dipping to the NW (Silva, 1994; Leyva Cabello et al., 2010). Furthermore, it has also been interpreted as the possible SW prolongation of the Carrascoy Fault (Insua-Arévalo et al., 2012). However, in this paper we show that the LTF is a leftlateral reverse fault, highly dipping to the SE with a strike and a style of deformation which differ from the Carrascoy Fault, suggesting an independent kinematic behaviour. Additionally, we show that the LTF has a remarkable Holocene activity, with the occurrence of at least two paleoearthquakes. Such a seismic activity disagrees with the subtle topographic expression of the fault when compared with the substantially faulted mountain fronts developed in the area, pointing out the recently formed character of the LTF (Middle Pleistocene) included in the broader EBSZ structure.

\section{Geological setting}

The LTF is located at the Eastern Betic Cordillera, within the Internal Zones of the cordillera (Fig. 1). The Betic Cordillera, together with the Moroccan Rif, forms the western end of the Mediterranean Alpine Orogen. The Internal Zones, also named Units of the Alboran Domain (Balanyá and García Dueñas, 1987), are built up of a stack of tectosedimentary complexes (Nevado-Filabride, Alpujarride, and Malaguide) of Paleozoic, Mesozoic and Tertiary materials during the Paleogene that forms the Alpine Orogen (Egeler and Simon, 1969). The neotectonic period began $9 \mathrm{Ma}$ at this eastern sector of the Betic Cordillera. This period is controlled by a compressive tectonic regime with a maximum horizontal shortening oriented NW-SE (Sanz de Galdeano, 1990) related to the convergence between the Eurasian and Nubian plates (Livermore and Smith, 1985; Dewey et al., 1989). Recent local GPS measurements from the CuaTeNeo network agree with a regional NNW-SSE shortening direction in the central and eastern Betics, but to the southeast of the LTF the GPS velocity vectors show a clockwise rotation to NNESSW (Khazaradze et al., 2008; Echeverria et al., 2011).

During the neotectonic period, the tectonic deformation of this sector of the cordillera has developed a large strikeslip tectonic corridor, affecting both basement rocks (Internal Zones) and Neogene and Quaternary deposits (Fig. 1). The EBSZ is a singular tectonic feature that controls the movement of the eastern crustal block of Campo de Cartagena towards the NE. Several Plio-Quaternary basins controlled by faults have been developed along the EBSZ (Silva et al., 1993).

The main basin within the EBSZ is known as the Guadalentin Depression. The Guadalentin Depression is an elongated NE-SW tectonic corridor drained by the Guadalentin River (also named Sangonera River) until it flows into the Segura River, to the east of the city of Murcia (Fig. 2). The basin has a complex infilling history with a transition from marine to continental environments during the Plio-Pleistocene (Leyva Cabello et al., 2010), reaching the Holocene as an endorheic basin at its southernmost part (South of Alhama de Murcia town) (Silva et al., 2008). The basin is sharply bounded by the uplifted Late Neogene deposits of the Lorca and Fortuna Basins and the Espuña Range (Internal Zones) to the northwest. The contact between these reliefs and the Guadalentin Depression is controlled by the Alhama de Murcia Fault (AMF) (Bousquet, 1979). The AMF dominates one of the major active range-fronts in the Eastern Betic Chain (Silva et al., 1993). It records important accumulated left-lateral slip (8 to $20 \mathrm{~km}$ ) from the Messinian to the present (Weijermars, 1987; Silva et al., 1997), but also a significant tectonic 


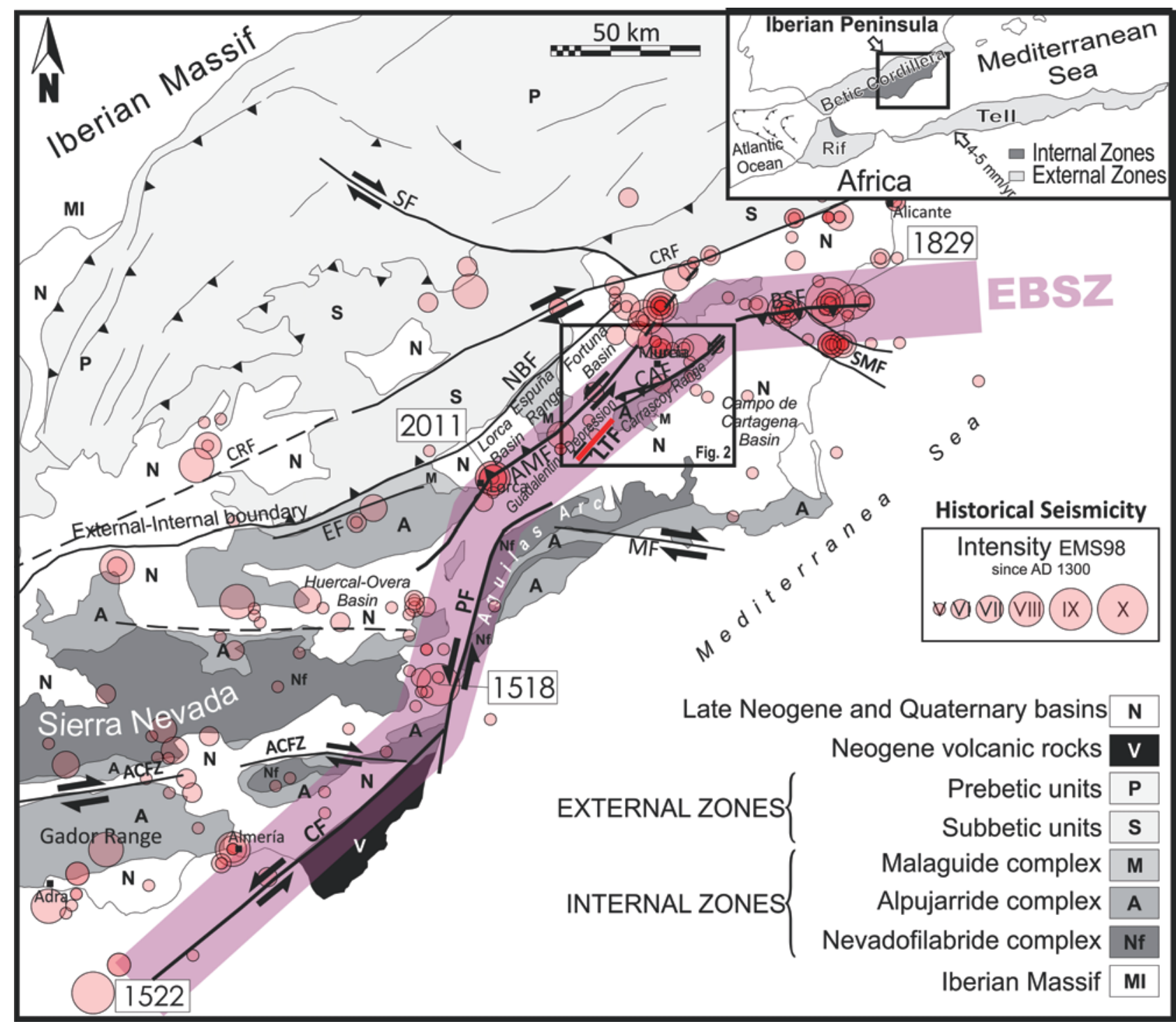

Fig. 1.- Geological setting of the study area. The convergence vector between Africa and Eurasia are shown. EBSZ: Easter Betic Shear Zone; BSF: Bajo Segura Fault; CAF: Carrascoy Fault; LTF: Los Tollos Fault (in red and thicker trace); AMF: Alhama de Murcia Fault; PF: Palomares Fault; CF: Carboneras Fault; SF: Socovos Fault; CRF: Crevillente Fault; SMF: San Miguel de Salinas Fault; NBF: North Betic Fault; MF: Las Moreras Fault; ACFZ: Alpujarras Corridor Fault Zone. The year of the main historical earthquakes are displayed. Inset marks the location of Figure 2.

uplift (0.04-0.35 mm/yr since Tortonian) (Martínez-Díaz et al., 2012b). Paleoseismological studies show Quaternary slip-rate between 0.08 and $0.5 \mathrm{~mm} / \mathrm{yr}$ (Masana et al., 2004; Martínez-Díaz et al., 2012a; Ortuño et al., 2012).

The southeastern margin of the Guadalentin Depression presents two different sectors. On one hand, the northernmost sector is bounded by the remarkable relief of the Carrascoy Range (Fig. 2). The range consists of metamorphic materials from the Internal Zones (phyllites, quartzites, metabasites, sandstones, marbles) in addition to Neogene marine sediments. The Carrascoy Range presents an active range-front controlled by the Carrascoy Fault (CAF) that to the northeast connects to the Bajo Segura Fault (BSF) (Gauyau et al., 1977; Montenat et al., 1990; Silva et al., 1993), a pure reverse blind fault affecting Holocene deposits (Alfaro et al. 2002; Alfaro et al. 2012; Perea et al, 2012).
The CAF splits into two strands. The main relief is bounded by the North Carrascoy Fault, where the Internal Zones form the hanging wall of a south-dipping, high angle, leftlateral strike slip fault with reverse component (Silva, 1994; Sanz de Galdeano et al., 1998). This fault strand affects up to the Tortonian deposits. The other strand of the CAF is located to the north, named the Cañaricos-Cuevas del Norte Fault, which offsets the Middle to Late Pleistocene alluvial fans coming from the range (Silva, 1994). The maximum uplift rate of the range is estimated in $0.2 \mathrm{~mm} / \mathrm{yr}$ since the Upper Tortonian (Sanz de Galdeano et al., 1998), with a net slip-rate of $0.54 \mathrm{~mm} / \mathrm{yr}$ for the CAF considering a rake of $20^{\circ}$ (GarcíaMayordomo and Álvarez-Gómez, 2006).

On the other hand, the southernmost sector of the margin of the Guadalentin Depression, is not bounded by any significant relief, but just by some smooth hills developed over 


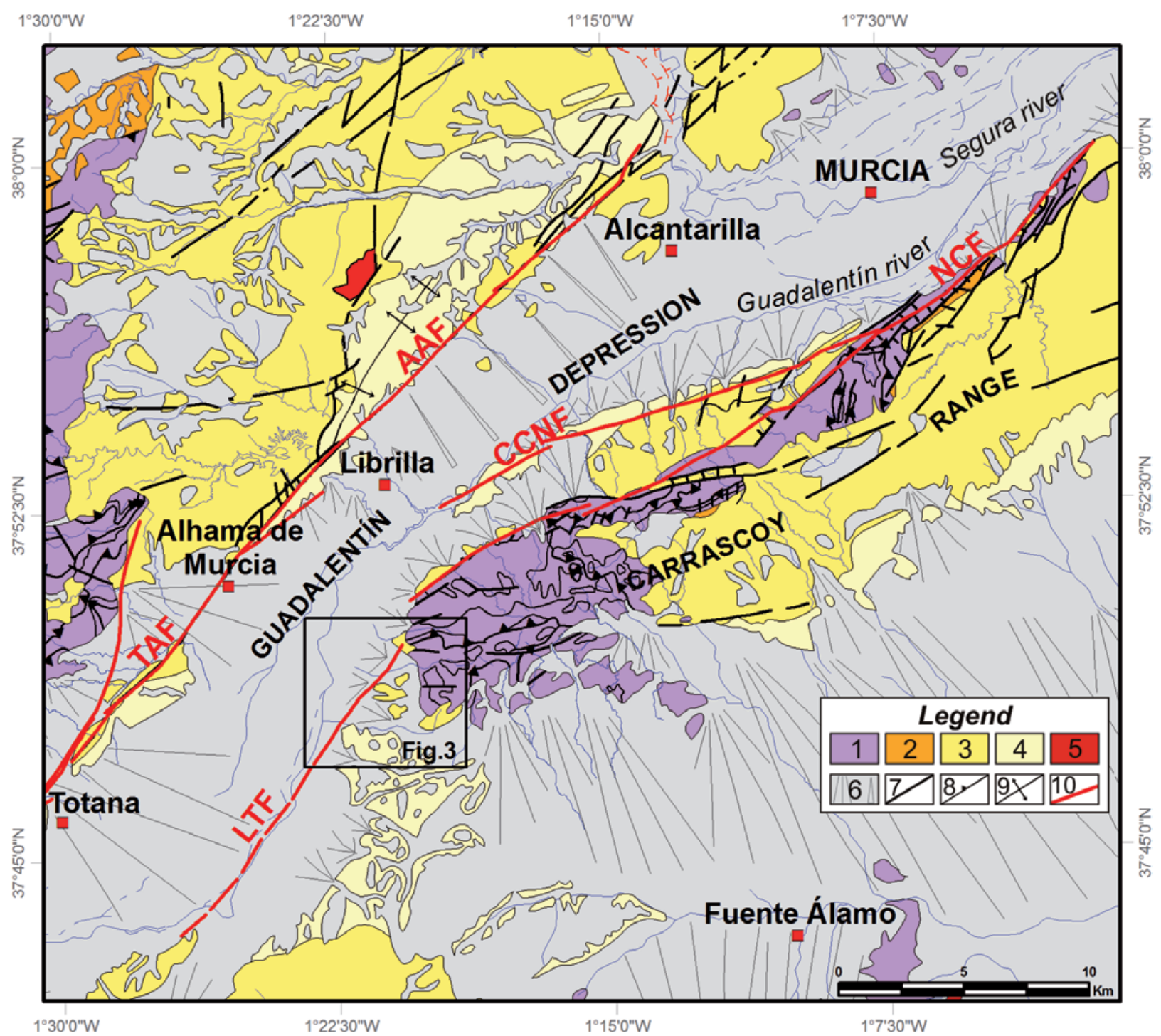

Fig. 2.- Local tectonic frame of Los Tollos Fault (LTF). Strands of the Carrascoy Fault: CCNF: Cañaricos-Cuevas del Norte Fault; NCF: Norcarrascoy Fault. Segments of the Alhama de Murcia Fault: TAF: Totana-Alhama; AAF: Alhama-Alcantarilla. 1: Internal Zones; 2: Early-Middle Miocene; 3: Neogene; 4: Pliocene-Early Pleistocene; 5: Neogene volcanic rocks; 6: Quaternary deposits; 7: Fault; 8: Thrust; 9: Anticline; 10: Quaternary active fault. Inset marks the location of Figure 3.

Plio-Quaternary deposits. Such a subtle relief represents a morphotectonic gap between the fault-generated mountains controlled by the CAF and the Palomares Fault (PF), located southwards. The PF consists on a subvertical east dipping normal fault with sinistral strike-slip component affecting Lower-Middle Pleistocene deposits (Silva, 1994).

The LTF is located in this morphotectonic gap of the depression. Nevertheless, this gap isolates the Guadalentin basin from the Campo de Cartagena basin, highlighting a substantial relief.

\section{Methodology}

The study of the LTF has been addressed from different points of view. First, a detailed cartography (scale 1:10,000) has been made considering geological and geomorphological aspects. The cartography is based on previous geological maps, aerial photo interpretation, field survey and digital terrain model analysis. Stratigraphy is mainly based on works from Leyva Cabello et al. (2010) and Silva (1994). We have interpreted aerial photographs from different flights and orthophotos at different scales $(>1: 33,000)$ obtained during the last 70 years $(1945,1957,2011$ and 2012).

Subsequently, four suitable sites were selected for trenching along the LTF, according to the presence of modern materials that could be affected by the latest surface-rupture earthquakes $(M>6.0)$ related to the LTF. The trenches were dug perpendicular to the fault trace, with a length between 8 and $70 \mathrm{~m}$, reaching $5 \mathrm{~m}$ of maximum depth. From north to south the trenches have been labelled as: Hueso, Acopios 1, Acopios 2, and Rio.

In order to date the units exposed in the trenches and define the seismic history of LTF, several representative samples were taken from different stratigraphic units. All the samples 


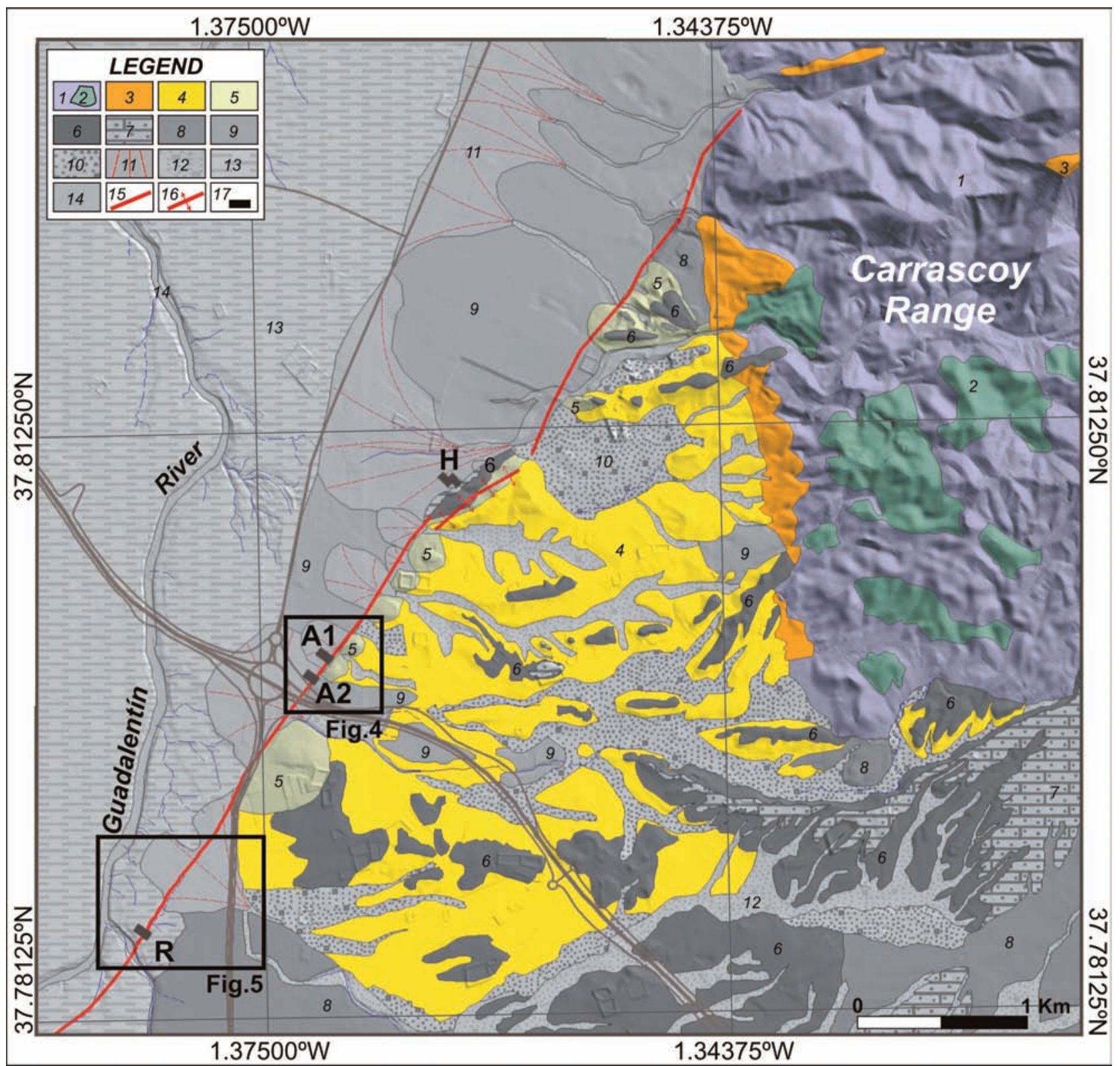

Fig. 3.- Geological map of the study area over a digital elevation model (modified and resurveyed from Leyva et al., 2010). 1: Alpujarride Complex; 2: Metabasites and amphibolites ; 3: Tortonian; 4: Messinian; 5: Pliocene - Early Pleistocene deposits; 6: Early-Middle Pleistocene alluvial fan deposits; 7: Early- Middle Pleistocene calcretes; 8: Middle Pleistocene alluvial fan deposits; 9: Upper Pleistocene-Holocene alluvial fan deposits; 10: Upper Pleistocene - Holocene alluvial-colluvial deposits; 11: Holocene alluvial fan deposits; 12: Holocene alluvial-colluvial deposits; 13: Holocene flood plain deposits; 14: Holocene torrential channel deposits; 15: Active fault; 16: Active anticline; 17: Trenches. The location of the trenches is marked: H: Hueso trench; A1: Acopios 1 trench; A2: Acopios 2 trench; R: Rio trench. Main roads are also displayed. Insets mark the location of Figures 4a, 5a and 5b.

have been dated by AMS-radiocarbon technique at Beta Analytic Inc. The obtained radiocarbon age for every sample has been calibrated by Beta Analytic following the INTCAL09.

We have used three types of samples for dating: charred material, bulk sediment, and gastropod shells. In case of stratigraphic discrepancy between samples, we have considered as more representative those ages provided by charred material. This consideration is based, on one hand, on the fact that dating bulk sediment may involve contamination by humic acids leaked from pedogenic processes taking place in upper levels, giving anomalous younger dates. Also, bulk sediment may include ancient reworked materials, especially in this kind of environments with little transport, giving an anomalous older age. On the other hand, a systematically older radiocarbon date is observed from those samples from gastropod shells within a given unit (see data at Table 1). This divergence can be explained by the incorporation of "dead" ${ }^{14} \mathrm{C}$ from carbonate rocks when gastropods built their shell (cf. Pigati et al., 2010). This effect is known as the "Limestone Problem" and can cause ${ }^{14} \mathrm{C}$ ages from gastropods shells to be a few thousand years older than the actual time of deposition (Goodfriend and Stipp, 1983). 


\begin{tabular}{|c|c|c|c|c|c|c|}
\hline SAMPLE & TRENCH & WALL & UNIT & DATED MATERIAL & CONVENTIONAL AGE & 2 SIGMA CALIBRATION (95\% confidence) \\
\hline A1N-4 & Acopios 1 & NE & D2 & organic sediment & $2,420+/-30 \mathrm{BP}$ & $\begin{array}{l}\text { Cal BC } 740 \text { to } 690 \text { (Cal BP } 2,690 \text { to } 2,640) \\
\text { Cal BC } 660 \text { to } 650 \text { (Cal BP } 2,610 \text { to } 2,600) \\
\text { Cal BC } 550 \text { to } 400 \text { (Cal BP } 2,500 \text { to } 2,350)\end{array}$ \\
\hline A1.30 & Acopios 1 & NE & $\mathrm{E}$ & snail shell & $10,240+/-40 \mathrm{BP}$ & Cal BC 10,140 to 9,870 (Cal BP 12,090 to 11,820$)$ \\
\hline A1N-3 & Acopios 1 & SW & D2 & organic sediment & $13,980+/-60 \mathrm{BP}$ & Cal BC 15,170 to 14,960 (Cal BP 17,120 to 16,910$)$ \\
\hline A1N-6 & Acopios 1 & SW & E & organic sediment & $2,650+/-30 \mathrm{BP}$ & Cal BC 840 to 790 (Cal BP 2,780 to 2,740$)$ \\
\hline A1N-7 & Acopios 1 & SW & $\mathrm{E}$ & organic sediment & $2,300+/-30 \mathrm{BP}$ & $\begin{array}{l}\text { Cal BC } 400 \text { to } 360 \text { (Cal BP } 2,350 \text { to } 2,310) \\
\text { Cal BC } 270 \text { to } 260 \text { (Cal BP } 2,220 \text { to } 2,210)\end{array}$ \\
\hline A 1.3 & Acopios 1 & SW & $\mathrm{F}$ & charred material & $1,790+/-30 \mathrm{BP}$ & $\begin{array}{l}\text { Cal AD } 130 \text { to } 260 \text { (Cal BP } 1,820 \text { to } 1,690) \\
\text { Cal AD } 280 \text { to } 330 \text { (Cal BP } 1,670 \text { to } 1,620)\end{array}$ \\
\hline A2.6 & Acopios 2 & NE & D1 & snail shell & $>43,500 \mathrm{BP}$ & \\
\hline A2.7 & Acopios 2 & NE & D1 & organic sediment filling snail shell & $11,460+/-50 \mathrm{BP}$ & Cal BC 11,440 to 11,310 (Cal BP 13,400 to 13,260$)$ \\
\hline A2.2 & Acopios 2 & SW & D1 & organic sediment filling snail shell & $22,170+/-90 \mathrm{BP}$ & Cal BC 24,910 to 24,310 (Cal BP 26,860 to 26,260$)$ \\
\hline A2.1 & Acopios 2 & SW & D1 & organic sediment filling snail shell & $7,980+/-40 \mathrm{BP}$ & $\mathrm{Cal} \mathrm{BC} 7,050$ to $6,700(\mathrm{Cal} \mathrm{BP} 9,000$ to 8,650$)$ \\
\hline A2.3 & Acopios 2 & SW & $\mathrm{F}$ & organic sediment & $2,210+/-30 \mathrm{BP}$ & Cal BC 380 to 200 (Cal BP 2,330 to 2,140$)$ \\
\hline $\mathrm{R} 1.23$ & Rio & $\mathrm{NE}$ & $\mathrm{D}$ & charred material & $2,530+/-30 \mathrm{BP}$ & $\begin{array}{l}\text { Cal BC } 790 \text { to } 730 \text { (Cal BP } 2,740 \text { to } 2,680) \\
\text { Cal BC } 690 \text { to } 660 \text { (Cal BP 2,640 to } 2,610) \\
\text { Cal BC } 650 \text { to } 540 \text { (Cal BP } 2,600 \text { to } 2,490)\end{array}$ \\
\hline $\mathrm{RN}-1$ & Rio & SW & A & organic sediment & $3,580+/-30 \mathrm{BP}$ & $\begin{array}{l}\text { Cal BC } 2,020 \text { to } 1,990(\mathrm{Cal} \text { BP } 3970 \text { to } 3940) \\
\text { Cal BC } 1,980 \text { to } 1,880(\mathrm{Cal} \text { BP } 3,930 \text { to } 3,830)\end{array}$ \\
\hline $\mathrm{RN}-4$ & Rio & SW & A & organic sediment & $10,020+/-50 \mathrm{BP}$ & Cal BC 9,810 to 9,320 (Cal BP 11,760 to 11,270$)$ \\
\hline $\mathrm{R} 1.21$ & Rio & SW & A & organic sediment filling snail shell & $6,380+/-40 \mathrm{BP}$ & $\mathrm{Cal} \mathrm{BC} 5,470$ to $5,300(\mathrm{Cal} \mathrm{BP} 7,420$ to 7,250$)$ \\
\hline $\mathrm{R} 1.21$ & Rio & SW & A & snail shell & $11,050+/-50 \mathrm{BP}$ & Cal BC 11,140 to 10,820 (Cal BP 13,090 to 12,770$)$ \\
\hline $\mathrm{R} 1.20$ & Rio & SW & $\mathrm{H}$ & charred material & $190+/-30 \mathrm{BP}$ & $\begin{array}{l}\text { Cal AD } 1,650 \text { to } 1,690(\mathrm{Cal} \text { BP } 300 \text { to } 260) \\
\text { Cal AD } 1,730 \text { to } 1,810 \text { (Cal BP } 220 \text { to } 140) \\
\text { Cal AD } 1,920 \text { to post } 1,950 \text { (Cal BP } 30 \text { to post } 1,950)\end{array}$ \\
\hline R1.4 & Rio & SW & $\mathrm{I}-2$ & charred material & $1,190+/-30 \mathrm{BP}$ & $\begin{array}{l}\text { Cal AD } 730 \text { to } 740 \text { (Cal BP } 1,220 \text { to } 1,210) \\
\text { Cal AD } 770 \text { to } 900 \text { (Cal BP } 1,180 \text { to } 1,060) \\
\text { Cal AD } 920 \text { to } 940 \text { (Cal BP } 1,030 \text { to } 1,010)\end{array}$ \\
\hline R1.9 & Rio & SW & $\mathrm{J}$ & organic sediment & $2,000+/-30 \mathrm{BP}$ & Cal BC 50 Cal AD 70 (Cal BP 2000 to 1880$)$ \\
\hline $\mathrm{R} 1.24$ & Rio & SW & $\mathrm{K}$ & charred material & $1,250+/-30 \mathrm{BP}$ & $\begin{array}{l}\text { Cal AD } 680 \text { to } 830 \text { (Cal BP } 1,270 \text { to } 1,120) \\
\text { Cal AD } 840 \text { to } 870 \text { (Cal BP } 1,110 \text { to } 1,080)\end{array}$ \\
\hline $\mathrm{RN}-2$ & Rio & SW & $\mathrm{K}$ & organic sediment & $4,060+/-30 \mathrm{BP}$ & $\begin{array}{l}\text { Cal BC } 2,830 \text { to } 2,820 \text { (Cal BP } 4,780 \text { to } 4,770) \\
\text { Cal BC } 2,660 \text { to } 2,640 \text { (Cal BP } 4,610 \text { to } 4,590) \\
\text { Cal BC } 2,640 \text { to } 2,560 \text { (Cal BP } 4,590 \text { to } 4,510) \\
\text { Cal BC } 2,560 \text { to } 2,550 \text { (Cal BP } 4,500 \text { to } 4,500) \\
\text { Cal BC } 2,540 \text { to } 2,490 \text { (Cal BP } 4,490 \text { to } 4,440)\end{array}$ \\
\hline
\end{tabular}

Table 1.- AMS-radiocarbon dated samples. All the samples were dated by Beta Analytic Inc. The calendar calibrated ages are calculated by Beta Analytic from the conventional radiocarbon age and listed as two standard deviation calibrated results with a $95 \%$ confidence. Different intervals for calibrated ages represent different possible brackets of age. (BC: before Christ, AD: Anno Domini, BP: before Present).

\section{Morphological expression of the LTF}

The area where the LTF is located shows a subtle topographic expression when compared to the substantially faulted mountain fronts developed in the area. The fault trace extends even into the modern flat terrains of the eastern margin of the Guadalentin Depression (Fig. 2). In the northern sector of the LTF, adjacent to the Carrascoy Range, the fault trace delineates the NE-SW contact between Pliocene and Pleistocene deposits forming smooth hills and the recent Holocene filling of the depression (Leyva Cabello et al., 2010) (Figs. $3,4)$. The Pliocene and Pleistocene deposits belong to the upthrown block. Pliocene units, made up of marls and conglomerates, crop out in the northernmost sector of the fault trace. The overlying Pleistocene units correspond to alluvial fans coming from the Carrascoy Range. These Pleistocene deposits include pebbles and boulders of phyllites and quartzites, with a characteristic presence of metabasites (porphyritic rock, outcropping in the Carrascoy Range), in a silty or sandy matrix. The deposits have a distribution of grain sizes and degree of roundness that fits a pattern of medium to distal alluvial fan facies typical of this type of sedimentary systems.
Locally, these units exhibit a calcrete-crust with variable development. The youngest alluvial fans develop a depositional terrace pattern. The downthrown block of the fault records the transition from distal alluvial fan facies to the fluvialpalustrine environment of the Guadalentin Depression reaching up to Holocene times.

The morphological expression of the fault is clearer in the northern sector of the LTF in contrast with the southern one. The geomorphological signals of the fault become weaker in the southern sector where the fault trace reaches the deposits of the central part of the Guadalentin Depression. The fault trace has been identified by the analysis of aerial photographs dated from 1957 (Fig. 5). Here, the fault trace is detected by a subtle imprint in the drainage network. A straight linear creek drains a flat area following a NE-SW trend located at the prolongation of the trace of the fault that controls the aforementioned relief in the northern area. It can even be observed how the previous dendritic drainage network is captured by this straight channel. Nevertheless, nowadays almost the entire signal has disappeared because of the intense anthropic activity in the region. Only a lineament drawn by denser vegetation remains (Fig. 5c, 5d). 


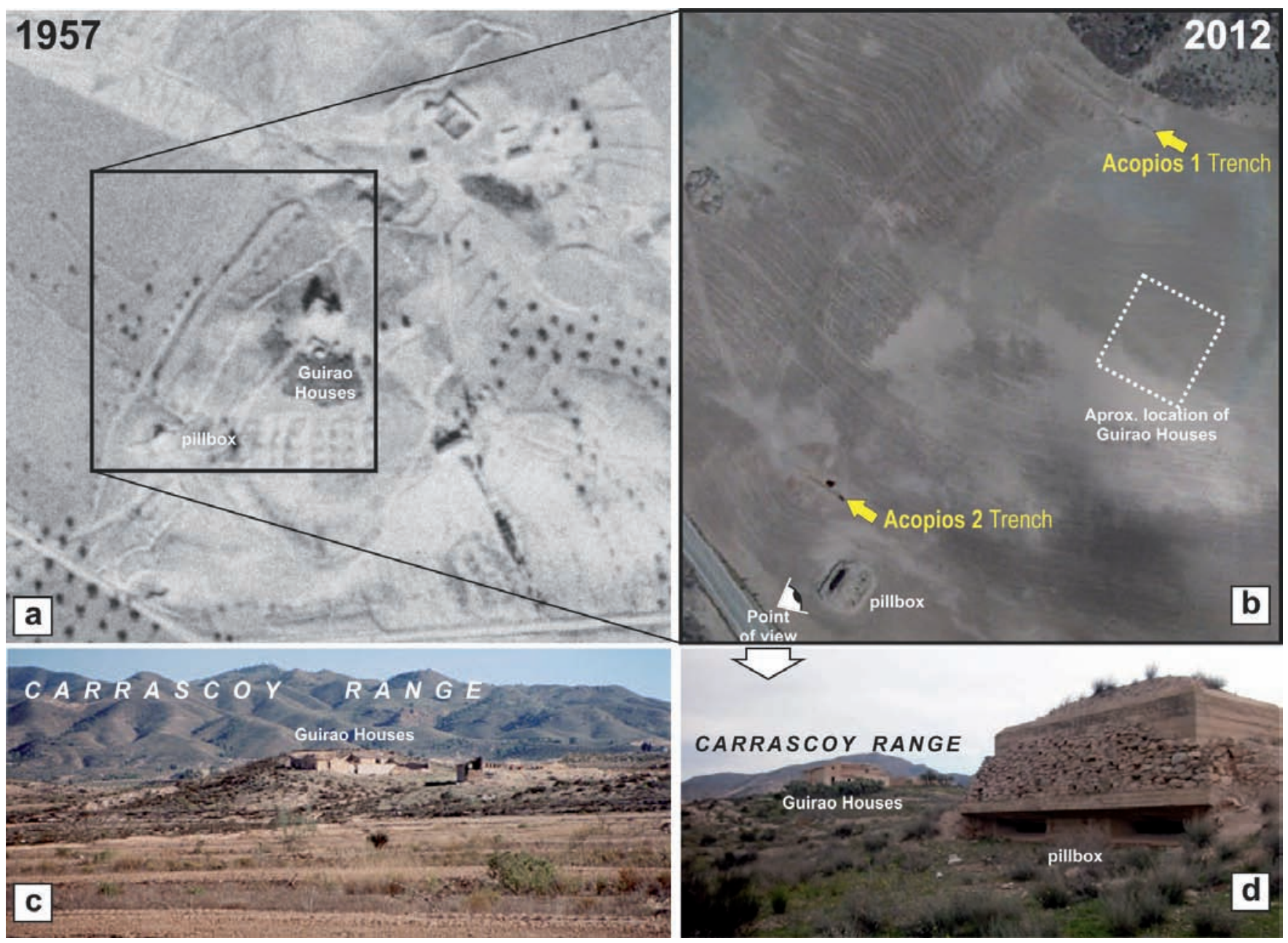

Fig. 4.- a) Aerial photograph from 1957 of the LTF trace in the area of Acopios 1 and 2 trenches. Location in Figure 3. b) 2012 aerial orthophoto of the area of Acopios trenches. The anthropic activity has removed the smooth hills where the old Guirao Houses were settled. Location of Acopios trenches during the paleoseismological works can be observed. c) A frontal view taken before 2011 of the hills associated to the activity of the LTF where the trenches Acopios 1 and 2 were dug (modified from the Archeological Catalogue of Murcia. Carta Arqueológica de la Región de Murcia, 2013). d) Oblique view of the same hills as in c) (Modified from Ayuntamiento de Alhama de Murcia, 2011).

The southward prolongation of the LTF has been inferred from seismic reflection profiles performed along and across the depression (Martínez del Olmo et al., 2006). Surface field observation of the fault is precluded because of the intense agricultural activity in this area, the youth of the alluvial plain and fluvial-palustrine deposits, and the predominant strikeslip kinematics of the fault. Nevertheless, the point where the surface projection of the fault cuts the southern bank of the Guadalentin River coincides with an area concentrating intense fracturing and gravitational slides. Additionally, from this point to the SW, the Guadalentin river shows a conspicuous NE-SW straight trend for $5 \mathrm{~km}$ approx. This morphologic feature is known as La Alcanara, interpreted as a channel dug during the Roman times to connect Guadalentin and Sangonera rivers (Silva et al., 2008), suggesting that the builders took advantage of a previous topography that may be controlled by the fault. The length of the whole fault trace, considering the Alcanara channel, is $15 \mathrm{~km}$.

\section{Paleoseismic study of the LTF}

\subsection{Trenches Acopios 1 and Acopios 2}

The trenches Acopios 1 (AT1) and Acopios 2 (AT2) were dug at a site where the original topography was completely modified due to a recent extraction of aggregates for the construction of a nearby road. Nevertheless, in the aerial photographs of 1957 the fault trace is clearly inferred to run along the foot of a couple of small hills, where a group of houses was originally located (the Guirao Houses, Fig. 4).

Within the walls of Acopios 1 and Acopios 2 a high angle (subvertical), south-dipping fault zone affecting alluvial fan deposits can be seen (Figs. 6, 7; a detailed description of the stratigraphic units can be seen in the legend of Fig. 6 which is common also to Fig. 7). The fault zone has a variable width between 1 and $2 \mathrm{~m}$ of shearing and deformation, with anastomosing fault planes and positive-flower structure, fitting the pattern of a strike slip fault (Woodcock and Fischer, 1986). 

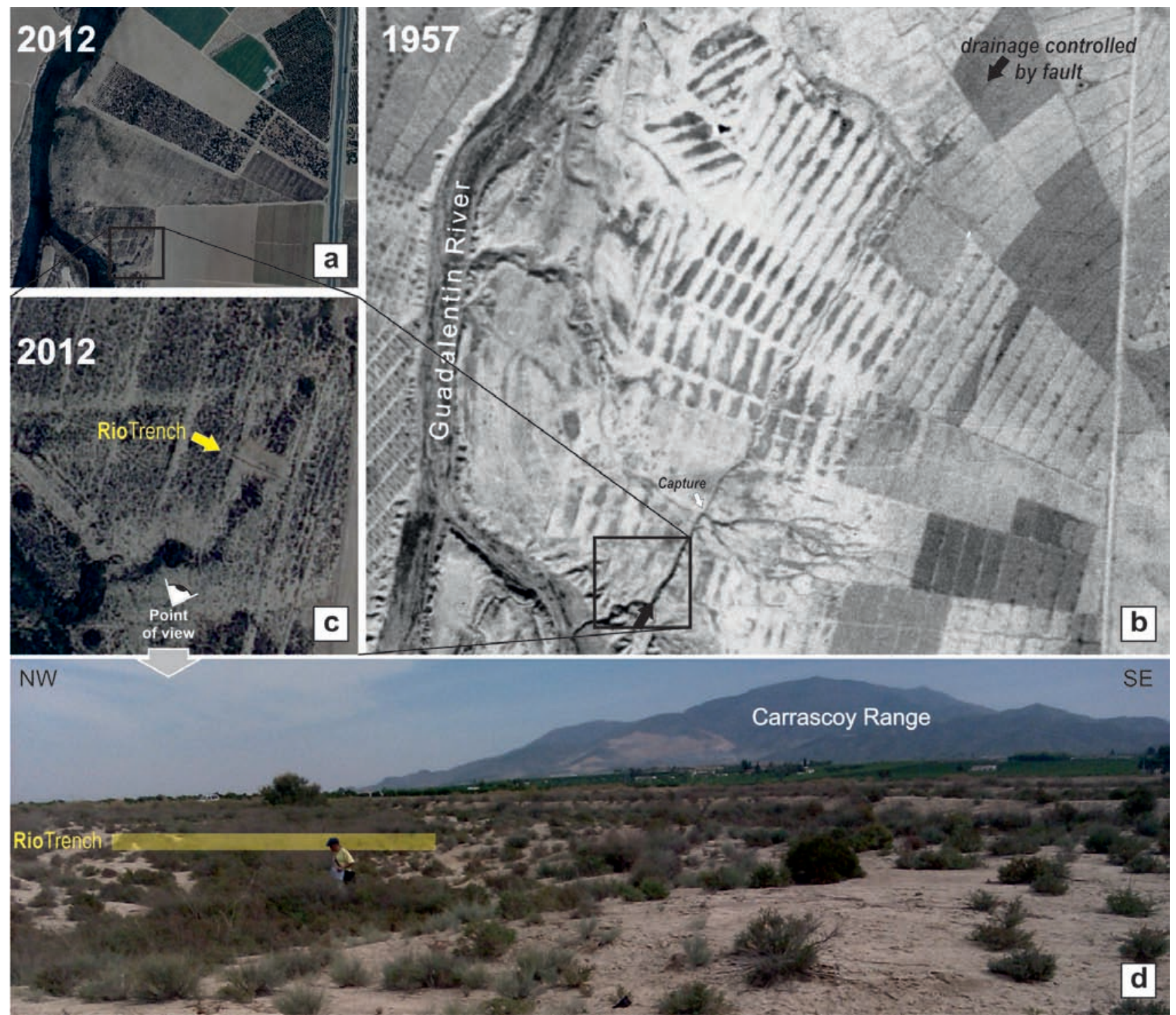

Fig. 5.- a) 2012 aerial orthophoto of the flat plain close to the Guadalentin River. Location in Figure 3. No significant signal of the fault trace can be identified because of the intense anthropic activity. b) Aerial photo of the same area taken in 1957. The control of the fault trace on the drainage network is shown (between the black arrows). Notice the capture (white arrow) of the dendritic drainage that makes it flow towards southwest instead of towards the northwest. c) Details of the morphological expression of the fault in 2012 (after the Rio trench digging). The location of the Rio trench can be observed. d) Field photo of the area before the trench digging. A conspicuous lineation of denser vegetation can be observed.

Despite the loose material affected by the fault, $15^{\circ} \mathrm{SW}$ rake striae have been identified (Fig. 7, SW wall), giving a leftlateral displacement with the downthrown block to the northeast, consistent with the original topography of the area previous to the extraction of aggregates.

The fault affects two different units of alluvial fan deposits: units D and C, from younger to older. In Acopios 2 (Fig. 7) it can also be observed that the underlying substrate (Unit B) is made up of fluvial, well-rounded conglomerates, and greenish silty marls. These formations are interpreted as the transition from marine conditions to a fluvial environment occurring from the Pliocene to Early Pleistocene times (Leyva et al., 2010). This substrate, due to its plastic behaviour, is sheared along the fault zone mixed with the overlying levels reaching more than $2 \mathrm{~m}$ up above their original position, which provides an estimate of the accumulated vertical displacement of the fault.

The youngest deposits identified in both trenches, apart from the anthropic top level (unit G), are units F and E (F younger than E). These units, attending to their relationship with the fault ruptures, pre- and post-date the seismic events. In the northeastern wall of Acopios 1 (Fig. 6), Unit E is affected by the northernmost strands of the fault. This fault strand is tapped by unit F. According to this geometry Unit F post-dates a seismic event that affected up to Unit E. On the other hand, Unit E post-dates a previous seismic event that affected at least up to Unit D1 (southernmost strands of the fault). Nevertheless, we cannot discard that this rupture also affected Unit D2, as nowadays it has been removed by the aggregates extraction. In Acopios 2 (Fig. 7), the northeastern 

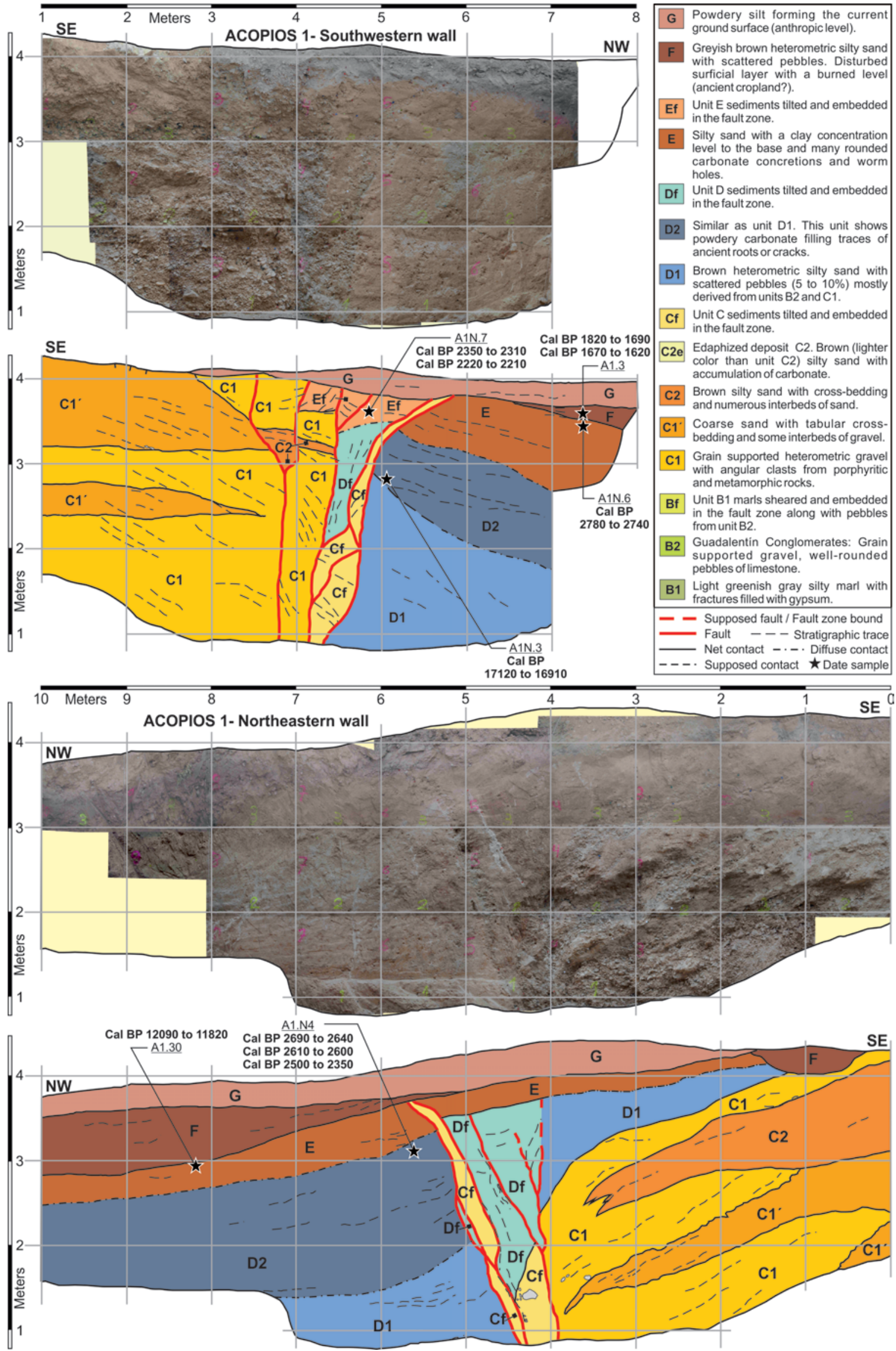

Fig. 6.- Photos and logs of both walls of the trench Acopios 1. The legend is common to Acopios 2 (Fig. 7). Unit E post-dates and pre-dates two seismic events. Unit $\mathrm{F}$ post-dates the last recorded seismic event (see text for details). 

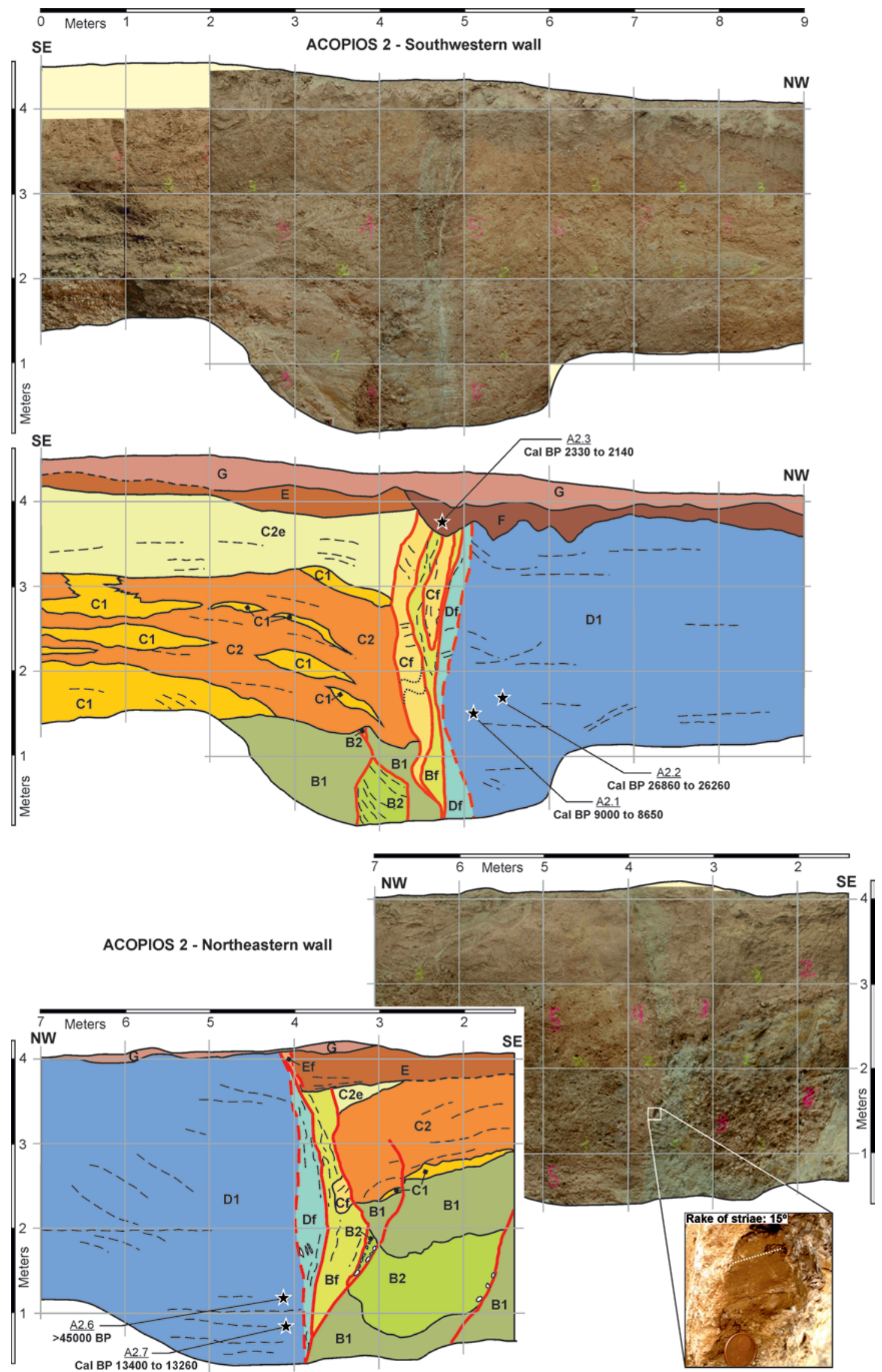

Fig. 7.- Photos and logs of both walls of the trench Acopios 2. Unit F post-dates the last registered seismic event that affected up to Unit D1. Unit $\mathrm{E}$ is affected by this last event, post-dating a previous one (see text for details). Fault striae found on the Northeastern wall is shown. Legend is common to Acopios 1 trench (Fig. 6). 
wall also shows that Unit $\mathrm{E}$ is affected by the northernmost strands of the fault. This fault strand is tapped by unit F. According to this geometry Unit $\mathrm{F}$ post-dates a seismic event that affected up to Unit E in the same way that occurred at AT1. At the southwestern wall of this trench, it can be observed again that Unit $\mathrm{F}$ is not affected by any seismic event (no fault strand ruptures it), thus post-dating the last one. It is interesting to mention that in AT1 the thickness of Unit E is located on the downthrown block, while in AT2 is on the upthrown block. This fact could be explained by a local change in the kinematics evidencing the strike-slip movement of the fault. Nevertheless, this fact could be also related to the erodability of Unit $\mathrm{C} 2$.

In order to understand the fault rupture history, we have considered several working hypothesis attending to the stratigraphic position of the samples and their calibrated radiocarbon ages (Table 1, Fig. 8). We have labelled them as preferred, possible, and unlikely. Our preferred working hypothesis (Fig. 8, solid line) takes into account the simple law of superposition (i.e.: the lower, the older). The samples along this solid line has been used as a reference age for constraining the date of seismic events. Observing the solid line (as well as the other working hypothesis lines), those samples out of the line to the right, and therefore anomalously younger, are interpreted as contaminated by recent pedogenic processes (by recent organic matter). On the contrary, those samples out of the line to the left, and therefore anomalously older, are interpreted either as reworked samples or in relation to the aforementioned "limestone problem" when radiocarbon dating is used in gastropod shells.

We consider as unlikely that working hypothesis which includes samples A1N-3 and A2.2, since that hypothesis would imply to discard the samples A2.1 and A2.7 interpreting them as contaminated by recent pedogenic processes. Such an interpretation is not very reliable regarding the depth where they were taken from.

The working hypothesis labelled as possible includes the maximum number of samples, which allow us to build also a stronger record. However, that would imply to interpret the sample A1N-6 as reworked, which is more difficult to justify since the nature of the dated material (organic sediment). Nevertheless, we consider this working hypothesis as possible.

We have identified the occurrence of at least two paleoseismic events. Unit $\mathrm{F}$ is the oldest unit without rupture, so it post-dates the last seismic event identified at Acopios $1 \mathrm{NE}$ wall (A1NE) and Acopios $2 \mathrm{SW}$ wall (A2SW) (Figs. 6, 7). Considering the age of the sample A1N-6 as representative of Unit E (preferred working hypothesis, solid line in Fig. 8), the youngest unit affected by the fault, we can estimate the occurrence of this event between 2,780 and 2,140 cal. yr BP. If we consider the age from sample $\mathrm{A} 1 \mathrm{~N}-7$ as representative of Unit E (possible working hypothesis, dashed line in Fig. 8 ), then it could be possible to constrain the range between 2,350 and 2,140 cal. yr BP. This is the last event identified in

\section{Cal BP (years)}

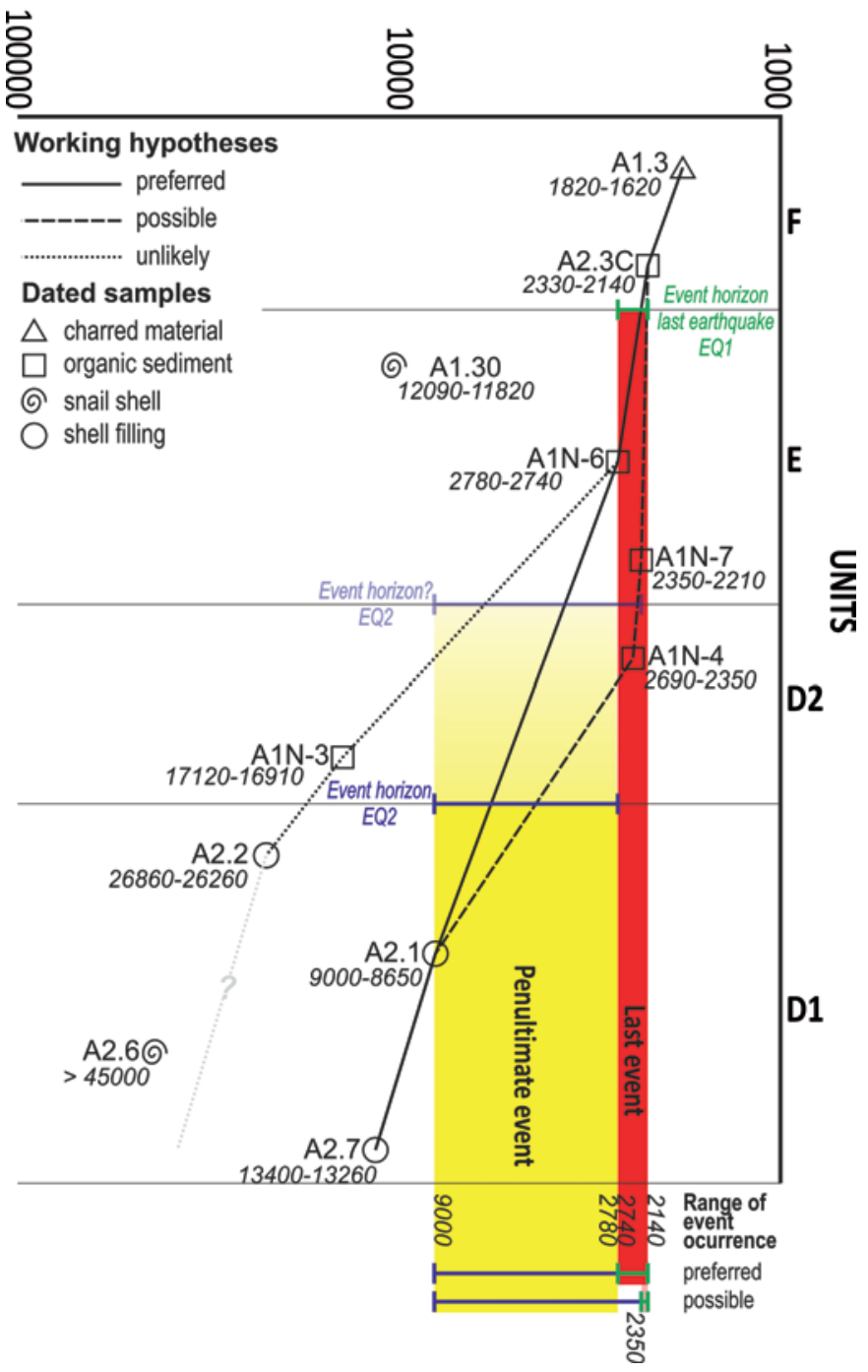

Fig. 8.- Age (x-axis) and stratigraphic position (y-axis) of the dated samples in Acopios 1 and Acopios 2 trenches. The label, type and calibrated ages of the samples are displayed. Regarding the displayed distribution, three working hypotheses have been defined in order to constrain the age for every sedimentary unit: preferred, possible, and unlikely. By considering the rupture relationships of the fault with the stratigraphic units (see figures 6 and 7), since Unit $F$ is not affected by any earthquake, Unit $\mathrm{E}$ is affected just by one (event horizon EQ1), and Unit D1 is affected by two (event horizon EQ2), at least two seismic events can be bounded: last and penultimate events. See text for details.

these trenches related to the LTF. The previous one did not affect Unit E (A1NE and A2NE), so it had to occur before its deposition, and therefore, before 2,740 cal. yr BP. This penultimate event did affect Unit D1, but we have not found any evidence of rupturing Unit D2 without affecting Unit E, so the oldest date reference has to be that from Unit D1. Hence a penultimate event might occur in an interval between 9,000 and 2,740 cal. yr BP. The intense deformation affecting the underlying Units $\mathrm{C}$ and $\mathrm{B}$ may be the result of the summation of a number of older events. 


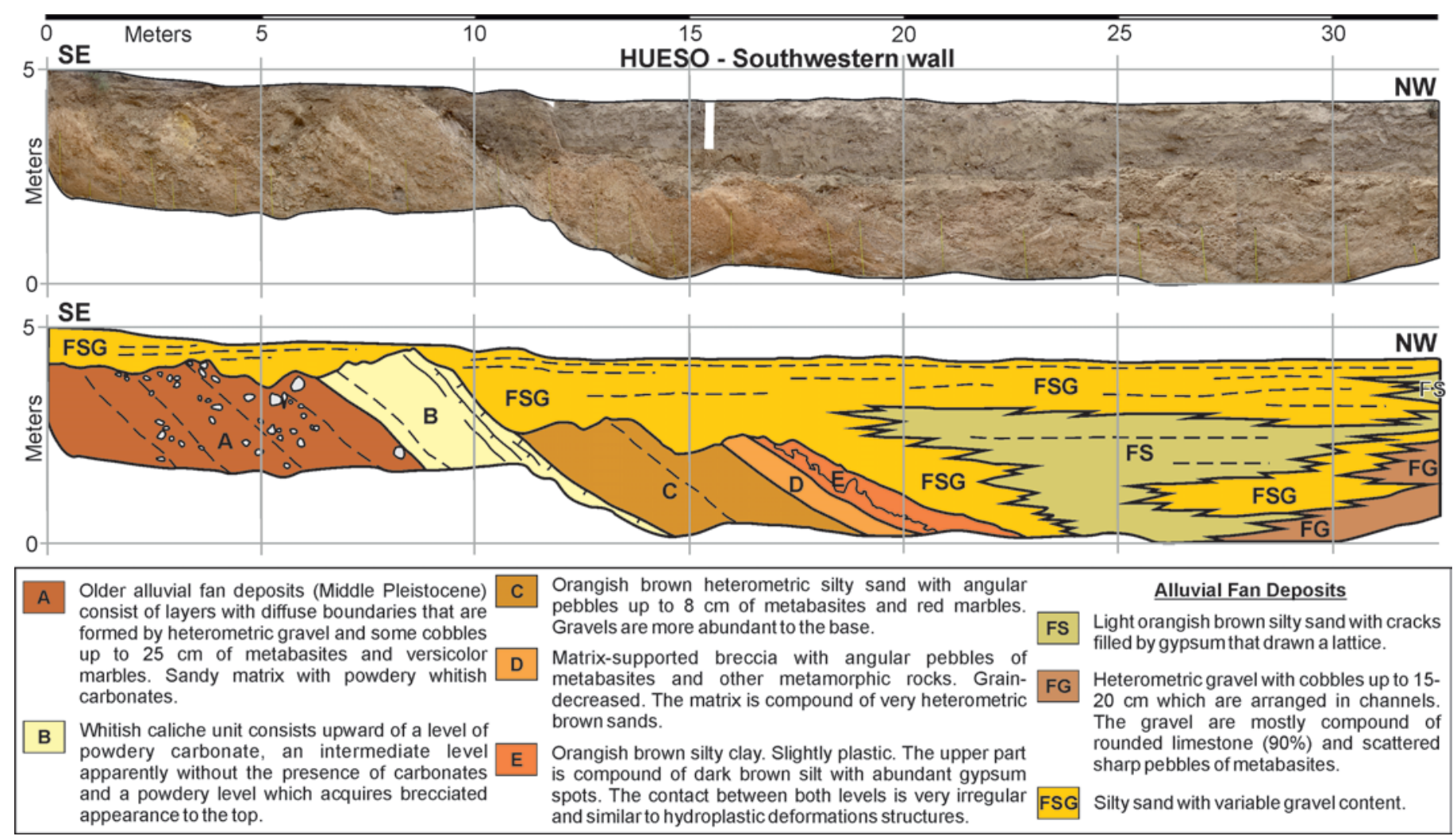

Fig. 9.- Photos and log of the southwestern side wall of the Hueso trench (see text for explanation).

Regarding to the distribution of the sedimentary units at both sides of the fault, the vertical offset can only be estimated for the last registered event by using the base of unit E. Unfortunately, the poor lateral continuity, the erosive base, the variable thickness or even the absence of this unit in some cases, together with the lateral movement of the fault, offer a wide range of values varying from 12 to more than $50 \mathrm{~cm}$. We consider as a realistic value that one measured at the base of unit $\mathrm{E}$ on the northeastern wall of Acopios 1 trench (Fig. 6) giving a value of $12 \pm 2 \mathrm{~cm}$.

\subsection{Hueso Trench}

The Hueso trench is the northernmost one along the LTF trace (Fig. 3). In this area the fault controls a conspicuous relief front that shows a hard calcrete-crust developed over Pleistocene alluvial fan deposits dipping towards northwest. The trench was placed cutting through a small alluvial fan coming out from the relief.

In the Hueso trench walls two main sedimentary formations can be distinguished (a detailed description of the stratigraphic units can be seen in the legend of Fig. 9). The oldest one (units A to E), at the lower part to the SE, corresponds to the Pleistocene alluvial fan deposits in which the calcretecrust was developed (unit B). The whole formation, up to unit $\mathrm{E}$, dips to the northwest. The dip is higher $\left(45^{\circ}\right)$ towards the SE while decrease towards the NW. The overlying formation (units FSG, FS, and FG) lies unconformably. This younger formation is also an alluvial fan deposit belonging to the sediments located all along the downthrown block of the fault trace. It shows massive layering with generalized lateral facies variation and evidence of channel incision. In such an environment it is difficult to distinguish clearly the dip of the formation.

The trench was dug for more than $70 \mathrm{~m}$ and no fault plane was found (Fig. 9). However, this trench provides valuable information confirming the oblique strike-slip character of the fault. We interpret this part of the trace as a fault restraining bend (Fig. 3). The northwest dipping older formation, which includes the calcrete-crust, would form the northern limb of an open NE-SW anticline that accommodates the deformation of this fault relay.

\subsection{Rio Trench}

The Rio trench (RT) was dug across a subtle elongated depression related to the current drainage network of the area (Fig. 5), as can be also seen in the topographic profile of the trench $\log$ (Fig 10). The trench had a length of $17 \mathrm{~m}$ and a depth of $4 \mathrm{~m}$; and it was dug in a NW-SE direction, perpendicular to the depression, and so to the surface-trace expression of the fault interpreted from aerial photography. The trench revealed a fairly horizontal sedimentary sequence disrupted by a topple landslide located in the central part. No evidence of unambiguous tectonic faulting was found in the trench. 


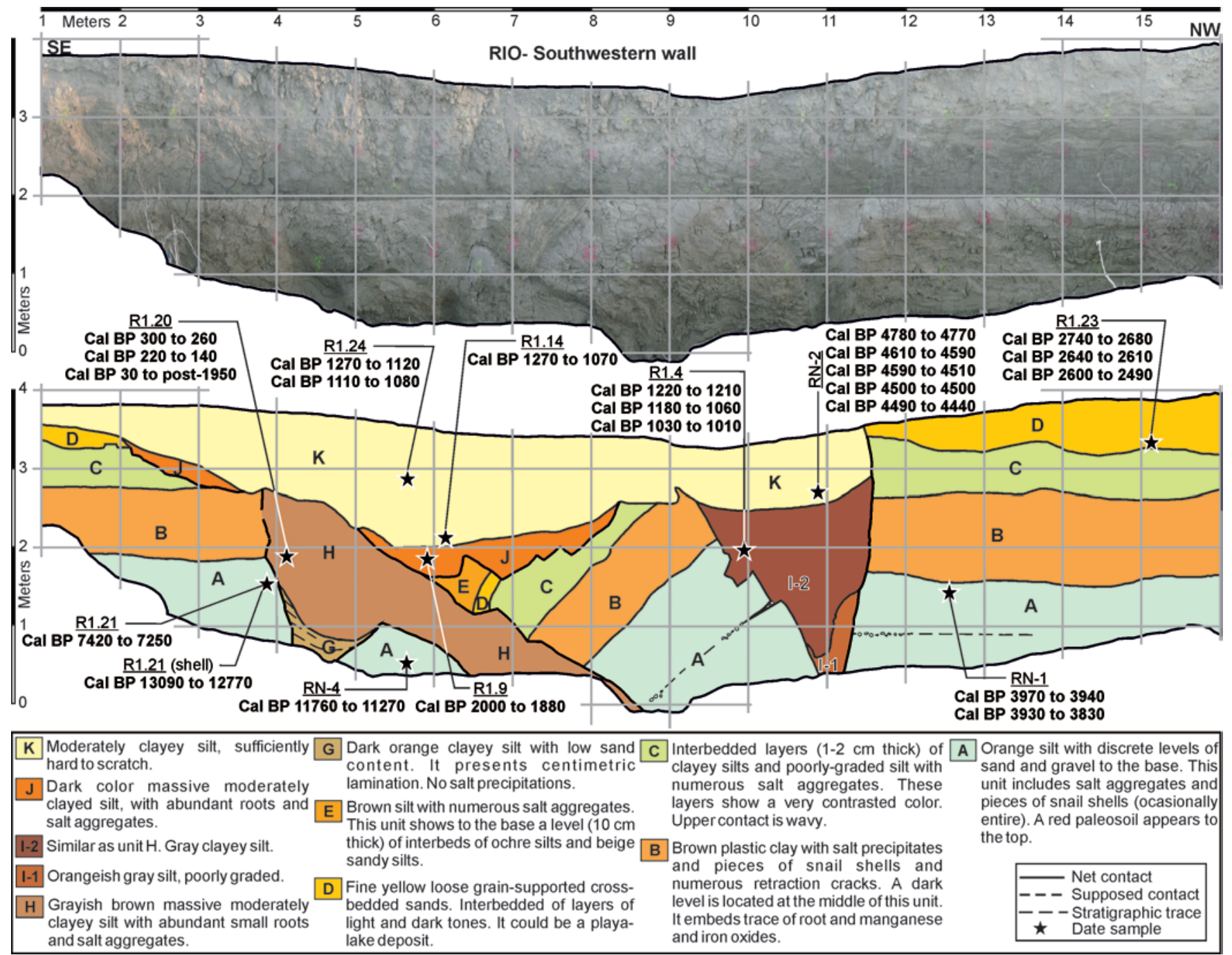

Fig. 10.- Photos and log of the southwestern side wall of the Rio trench (see text for explanation)

The horizontal sedimentary sequence (units A, B, C and D) (a detailed description of the stratigraphic units can be seen in the legend of Fig. 10) can be observed at both ends of the trench. The three first units (A, B and C) correspond to distal facies of alluvial fan deposits. The fourth (Unit D), together with a fifth one (Unit E), are made up of sediments deposited in a lacustrine and fluvio-palustrine environment. Unit E can be observed on the central part of the wall trench, overlying Unit D on top of the topple landslide. This toppled block lies over Unit $\mathrm{H}$, which together with Unit G filled up partially the rambla before the toppling. However, we cannot discard some piping and filling processes to explain any of these two units. Finally, the landslide mass is overlain by different loose, silty units (I, J and K) corresponding to different stages of the subsequent erosion and filling processes.

We interpret the distribution of the units to be the result of an external geodynamic process of slope failure or collapse involving an abrupt eroded channel, or even a piping process. Whatever the process, it must have been controlled by the previous presence of a weakness plane related to the LTF, regarding the straight linear pattern of the drainage network at this site (Fig. 5). Such a presence of a weakness plane implies the occurrence of a surface fault rupture affecting up to the uppermost sedimentary unit (Unit E). This unit formed the flat equilibrium surface by the time when the fault-rupture reached up to the ground surface, before the regional erosional episode. Subsequently, the drainage network incision evolved until the collapse of the "rambla" walls. The final unit distribution is completed by the subsequent sediment filling. Such an external process has obscured any signal of the fault plane which should be located in depth at the central part of the studied trench. Similar features can be observed $2 \mathrm{~km}$ to the SW, at the intersection of the fault with the right embankment of Guadalentin River, strongly suggesting that the fault trace controls the occurrence of sub-superficial erosive processes in these loose materials.

Regarding this interpretation, a seismic event with surface rupture related to the LTF in this site should have occurred after the deposition of unit $\mathrm{E}$ and before the onset of the erosion process. In order to date the occurrence of this seismic event, we have considered the radiocarbon dating obtained from a number of samples taken from units $\mathrm{D}$, and $\mathrm{G}$ to $\mathrm{K}$ 


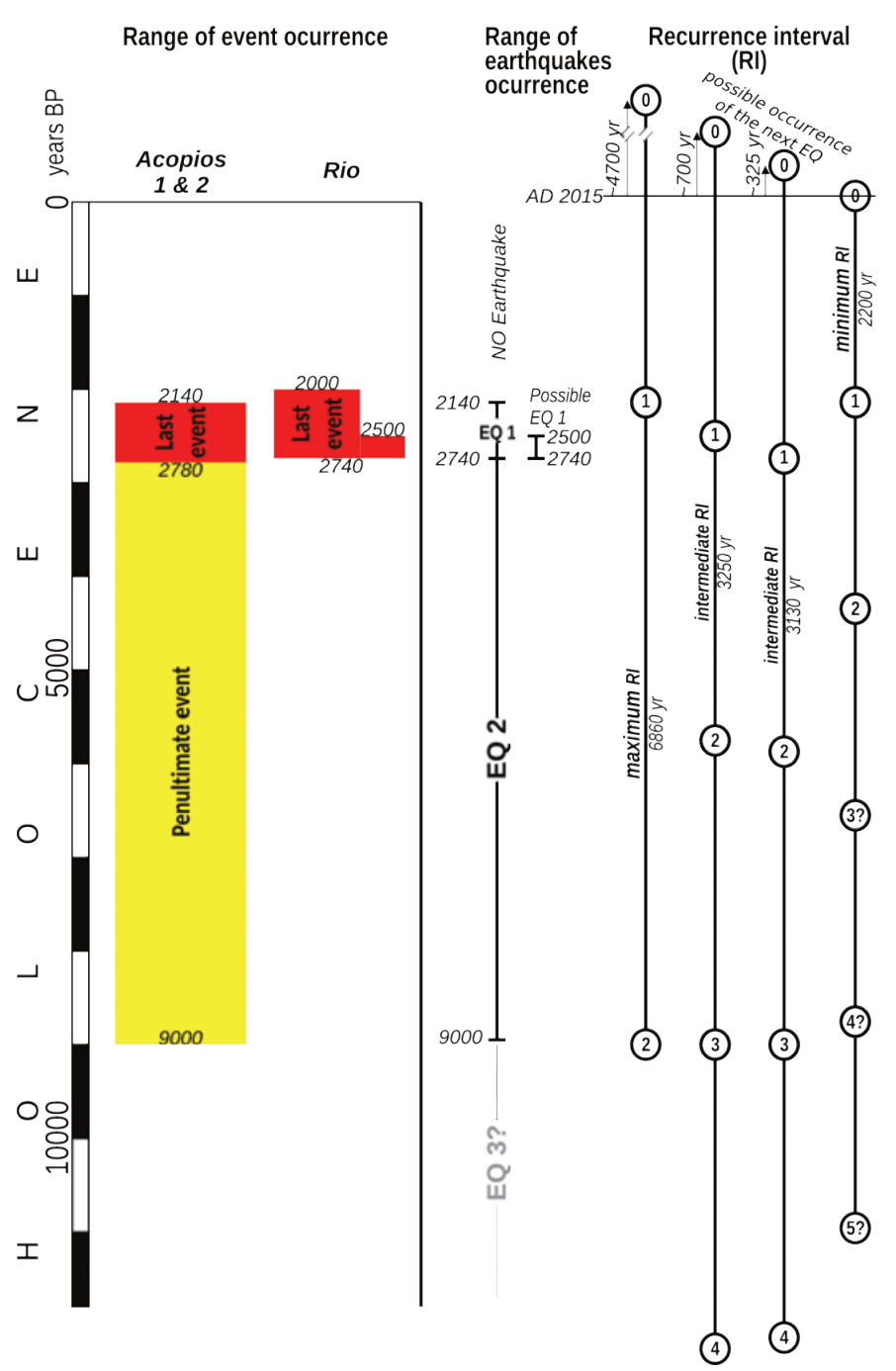

Fig. 11.- Time range of seismic events occurrence considering together the estimations in Acopios $1 \& 2$ and Rio trenches. EQ1: the last earthquake, EQ3: the oldest earthquake. Recurrence intervals are estimated considering different hypotheses. The circles represent seismic events (the higher, the older) spaced depending on the considered RI. $(0)=\mathrm{EQ} 0$ refers to the next earthquake to occur in the future.

(Table 1; sample positions given in Fig. 10). Based on the sample collected in unit $\mathrm{D}$, the youngest dated unit affected by the fault, we can estimate that the seismic event took place after 2,740 cal. yr BP. On the other hand, the subsequent erosion process can be dated from the samples taken from the filling deposits. These samples from $\mathrm{J}$ and $\mathrm{K}$ units range from 2,000 (R1.9, sediment) to 1,200 cal. yr BP for charred material sample, and 4,000 cal. yr BP for sediment, respectively. The latter value $(4,000$ cal. $y r$ BP, RN2, sediment) is not consistent with the other ages; its older age is interpreted as reworked old sediment. We interpret that the erosion process occurred before 2,000-1,880 cal. yr BP (sample R1.9). This age is consistent with the date given for the beginning of the main fluvial incision at this sector of the Guadalentin basin in $\sim 2,500$ cal. yr BP (Calmel-Avila, 2002). Therefore, the earthquake should have taken place between 2,740 and 1,880 (or 2,500) cal. yr BP.
Unfortunately, no other seismic events can be identified in this trench. However, the sedimentary sequence of Rio trench seems to appear relatively higher at the SE side than at the NW side, particularly the bottom contact of unit B. Even though this effect could be explained just considering a natural slight depositional slope (ca. $1^{\circ}$ ), it may be also related to vertical offset due to almost pure strike-slip faulting.

\section{Discussion}

According to empirical Mw scaling relationships and considering a $15 \mathrm{~km}$ surface rupture length, the LTF may produce earthquakes with magnitude $\mathrm{Mw}$ 6.3-6.6 (sensu Stirling et al., 2013). Two events have been identified in AT1 and AT2, and one in the RT. Taking into account the time distribution of these events in each trench, constrained by the age of the involved stratigraphic units, we have identified two earthquakes related to this fault within the Holocene (Fig. 11).

The last event identified in AT1 and AT2 between 2,780 and 2,140 cal. yr BP is consistent with the event identified in RT which occurred after 2,740 cal. yr BP. This evidence supports the occurrence of the last earthquake (EQ 1) between 2,740 and 2,140 cal. yr BP. This range of time could be bounded between 2,740 and 2,500 cal. yr BP if we consider the age of the regional fluvial incision (Calmel-Avila, 2002). This is the last earthquake with surface rupture produced by the LTF which is consistent with the lack of large historical earthquakes records in the seismic catalogue for this area (Fig. 1).

For the occurrence of previous events we can only consider the interpretation from AT1 and AT2. At least, one previous event occurred between 9,000 and 2,740 cal. yr BP. This would be a penultimate earthquake (EQ 2). Finally, an older earthquake is inferred attending to the intense deformation observed at AT1 and AT2 affecting the underlying units (EQ 3).

The identification of at least two earthquakes along the LTF and their time distribution, allows us to make a first estimation of the seismic recurrence interval (RI) (Fig. 11). A maximum RI results if we consider the occurrence of a single earthquake (EQ 2) between 9,000 and 2,740 cal. yr BP. The maximum RI reaches up to 6,860 years. If we assume a perfect characteristic earthquake model showing a constant periodic behaviour (cf. Scholz, 1992), this RI would imply the occurrence of the next earthquake (EQ 0) within the next $\sim 4,700$ years.

A minimum RI can be estimated taking into account that no earthquake has occurred since 2,140 cal. yr BP. Knowing that the reference-time for Present in radiocarbon dating is $\mathrm{AD}$ 1,950; the time elapsed since the last event (EQ1) is therefore $\sim 2,200$ years. This value can be taken as the minimum possible RI, as no major earthquake has yet occurred since the last one. A minimum value of 2,200 years for RI, assuming a perfect characteristic earthquake model, agrees the occurrence of a penultimate earthquake (EQ2) within the estimated range of time. However, we cannot confirm such a minimum RI solely from the data obtained in our trenches. 
DISPLACEMENT PER EVENT (cm)

\begin{tabular}{|c|c|c|c|c|c|c|c|c|}
\hline \multirow[b]{3}{*}{$\begin{array}{l}\text { Slip Rate } \\
(\mathbf{m m} / \mathbf{y r})\end{array}$} & \multicolumn{6}{|c|}{ Acopios 1 trench } & \multirow{2}{*}{\multicolumn{2}{|c|}{$\begin{array}{c}\begin{array}{c}\text { Empirical relationship } \\
(\mathrm{SRL}=15 \mathrm{~km})\end{array} \\
\text { W\&C94 }\end{array}$}} \\
\hline & \multicolumn{3}{|c|}{ Minimum } & \multicolumn{3}{|c|}{ Maximum } & & \\
\hline & vertical & horizontal & net & vertical & horizontal & net & $\begin{array}{c}\text { Average } \\
\text { net displ. }\end{array}$ & $\begin{array}{c}\text { Maximum } \\
\text { net displ. }\end{array}$ \\
\hline RI (years) & 10 & 37.7 & 38.6 & 14 & 52.2 & 54.1 & 33 & 47 \\
\hline 2,200 & 0.05 & 0.17 & 0.18 & 0.06 & 0.24 & 0.25 & 0.15 & 0.21 \\
\hline 3,130 & 0.03 & 0.12 & $\underline{0.12}$ & 0.04 & 0.17 & $\underline{\mathbf{0 . 1 7}}$ & 0.11 & 0.15 \\
\hline 3,250 & 0.03 & 0.12 & $\underline{0.12}$ & 0.04 & 0.16 & $\underline{0.17}$ & 0.10 & 0.15 \\
\hline 6,860 & 0.02 & 0.05 & 0.06 & 0.02 & 0.08 & 0.08 & 0.05 & 0.07 \\
\hline
\end{tabular}

Table 2.- Slip rate of the LTF calculated for different recurrence intervals (RI) and displacements considering a $15^{\circ}$ rake striae on a vertical fault plane, and from Wells and Coppersmith (1994) empirical relationships of average and maximum displacement on surface rupture length $(\mathrm{SRL}=15 \mathrm{~km})$. Preferred values defining a range are shown in bold. Preferred maximum and minimum values are shown underlined.

Intermediate credible values for RI can be estimated if we consider the occurrence of a third earthquake (EQ3) right before of the aforementioned range of occurrence for EQ2. Depending on the occurrence of EQ1, the RI varies between 3,130 and 3,250 years, bringing the occurrence of EQ0 within the next $\sim 325$ and $\sim 700$ years, respectively. These values of RI also imply the occurrence of three to four earthquakes within the Holocene. We could not identify unequivocally these possible earthquakes in our trenches but we cannot discard their occurrence within this period. The lack of record from these possible earthquakes in AT1 and AT2 could be explained by an erosional process that has removed the upper part of unit D2. On the other hand, the difference in height observed at the base of unit B at RT might be evidencing a coseismic vertical offset (Fig. 11).

A slip rate for the LTF can be estimated taking into account the RIs previously discussed, together with the minimum vertical displacement observed in the Acopios trenches (Table 2). A value of $12 \pm 2 \mathrm{~cm}$ for the vertical displacement has been considered as representative. Such value provides a net displacement between 39 and $54 \mathrm{~cm}$ when considering a $15^{\circ} \mathrm{SW}$ rake from the striae measured in AT2. These values are very consistent with the average $(33 \mathrm{~cm})$ and maximum $(47 \mathrm{~cm})$ displacement obtained from Wells and Coppersmith (1994) empirical relationships based on surface rupture length ( $\mathrm{SRL}=15 \mathrm{~km})$ (Table 2). Considering the four different RI discussed above, the complete set of possible net slip rate values would range from 0.06 to $0.25 \mathrm{~mm} / \mathrm{yr}$, being the range of 0.12 to $0.17 \mathrm{~mm} / \mathrm{yr}$ our preferred estimation, and $0.15 \mathrm{~mm} / \mathrm{yr}$ the mean.

The seismogenic parameters obtained here for the LTF (maximum magnitude, slip rate and recurrence interval) are fairly coherent with those obtained for other faults of the EBSZ (Table 3). Empirical estimation of the maximum magnitude of a fault is commonly derived from the length of the fault. It can be observed a consistency between this feature of the LTF and the other faults considering each of their segments. This observation might lead us to consider the LTF as a segment of a major structure together with the Carrascoy fault. However, it has been shown in on-going investigations
(Martín-Banda et al., 2014) that the active front of the Carrascoy fault shows pure reverse faulting with a low angle dipping plane (Cañaricos-Cuevas del Norte Fault, See Fig. 2), which does not fit the geometry and kinematics of the LTF. It can also be observed the lack of continuity between both fault traces. The activity of the LTF must be independent from the Carrascoy Fault, though both faults are related in the EBSZ context.

The values of slip rate for the LTF are consistent with the range of values from the other EBSZ faults. The recurrence interval of the LTF is also comparable with the rest of faults of the EBSZ, presenting the LTF one of the shortest ones. That would mean that the LTF has had a significant activity within the region. However, this situation disagrees with the subtle topographic expression of the fault if we compare it to the rest of the faults, which makes us to consider the LTF as a younger formed fault within the EBSZ. The beginning of the relative movement of the fault lifted up the southern

\begin{tabular}{|c|c|c|c|}
\hline FAULT / SEGMENTS & $\begin{array}{l}\text { Maximum } \\
\text { Magnitude }\end{array}$ & $\begin{array}{l}\text { Slip Rate } \\
(\mathrm{mm} / \mathrm{yr})\end{array}$ & $\begin{array}{l}\text { Recurrence } \\
\text { Interval (yrs) }\end{array}$ \\
\hline Bajo Segura Fault $^{(1)}$ & $6.9-7.1$ & $0.20-0.40$ & $7,434-13,973$ \\
\hline Guardamar & $6.6-6.8$ & $0.12-0.31$ & $8,716-21,495$ \\
\hline Benejuzar & $6.6-6.7$ & $0.16-0.41$ & $6,496-16,020$ \\
\hline Hurchillo & $6.6-6.8$ & $0.23-0.61$ & $4,446-10,963$ \\
\hline Carrascoy Fault ${ }^{(2)}$ & $6.6-6.8$ & 0.54 & $6,000-10,000$ \\
\hline Los Tollos Fault ${ }^{(*)}$ & 6.3-6.7 & $\begin{array}{l}\mathbf{0 . 1 2 - 0 . 1 7} \\
(0.06-0.25)\end{array}$ & $\begin{array}{l}\mathbf{3 , 2 0 0} \\
(2,220-6,860)\end{array}$ \\
\hline \multicolumn{4}{|l|}{ Alhama de Murcia Fautl(2,3) } \\
\hline Alhama-Alcantarilla & $6.2-6.8$ & $0.03-0.07$ & $13,000-35,000$ \\
\hline Totana-Alhama & $5.6-6.2$ & $?$ & $>>10,000$ \\
\hline Lorca-Totana & $6.5-6.7$ & 0.30 & $2,000-5,000$ \\
\hline Goñar-Lorca & $6.9-7.1$ & 0.50 & $7,000-10,000$ \\
\hline \multicolumn{4}{|l|}{ Palomares Fault ${ }^{(2)}$} \\
\hline S. Almenara-S Hinojar & $6.0-6.5$ & 0.05 & $>>10,000$ \\
\hline Carboneras-S. Almenara & $6.2-6.3$ & 0.04 & $10,000-30,000$ \\
\hline \multicolumn{4}{|l|}{ Carboneras Fault ${ }^{(2)}$} \\
\hline North & 7.1-7.7 & 1.10 & 13,500 \\
\hline South & $6.6-7.2$ & 0.04 & $?$ \\
\hline
\end{tabular}

Table 3.- Seismogenic parameters of the faults and fault segments forming the EBSZ. 
block, what could have blocked the access to the Mediterranean Sea of the Guadalentin River through the Campo de Cartagena basin, producing an endorheic environment (Silva et al., 2008) on the northern downthrown block. Hence, the age of formation of the fault could be related with the onset of the endorheic conditions of the Guadalentin Depression after the blockage of the river flow to the SE at the end of the Middle Pleistocene (Silva, 1994).

\section{Conclusions}

The geomorphic and paleoseismological evidence described in this work point out the existence of a new Quaternary tectonic feature, the Los Tollos Fault (LTF), within the Eastern Betic Shear Zone (EBSZ). The LTF is a left lateral strike-slip fault affecting Holocene deposits. At least two earthquakes have been identified during the Holocene. The last one occurred between 2,740 and 2,140 cal. yr BP, and a previous one between 9,000 and 2,740 cal. yr BP. Regarding the time distribution of the identified earthquakes, a recurrence interval in the range of 2,200 to 6,860 years has been estimated. We have calculated a net offset between 39 and $54 \mathrm{~cm}$, which is consistent with the empirical relationships of Wells and Coppersmith (1994). These values provide a range of possible net slip rate from 0.06 to $0.25 \mathrm{~mm} / \mathrm{yr}$, being our preferred estimation in the range $0.12-0.17 \mathrm{~mm} / \mathrm{yr}$. We have estimated a total fault length of $15 \mathrm{~km}$, capable to generate a potential maximum magnitude earthquake between Mw 6.3-6.6.

The Los Tollos Fault should be considered in future seismic hazard assessments in the region due to its close location to densely populated villages and to downtown Murcia, the largest city of the region with almost half a million inhabitants.

\section{Acknowledgments}

This work forms part of the research activities carried out in the FASEGEO Project (CGL2009-09726) funded by the Spanish Ministry of Science and Innovation. The authors greatly appreciate the carefully revision of Héctor Perea and Iván Martín Rojas that lead to an improved version of the manuscript.

\section{References}

Alfaro, P., Andreu, J.M., Delgado, J., Estévez, A., Soria, J.M., Teixidó, T. (2002): Quaternary deformation of the Bajo Segura blind Fault (eastern Betic Cordillera, Spain) revealed by high-resolution reflection profiling. Geological Magazine 139, 331-341. doi:10.1017/ S0016756802006568.

Alfaro, P., Bartolome, R., Borque, M.J., Estévez, A., García-Mayordomo, J., García-Tortosa, F.J., Gil, A.J., Gracia, E., LoIacono, C., Perea, H. (2012): The Bajo Segura Fault Zone: Active blind thrusting in the Eastern Betic Cordillera (SE Spain). Journal of Iberian Geology 38, 271-284. doi: 10.5209/rev_JIGE.2012.v38.n1.39217
Ayuntamiento de Alhama de Murcia (2011): Catálogo de Protección Etnográfico, $263 \mathrm{pp}$.

Balanyá, J.C., García-Dueñas, V. (1987): Les directions structurales dans le Domaine d'Alborán de part et d'autre du Détroit de Gibraltar. Comptes Rendus de l'Académie des Sciences 304, 929-933.

Banda, E., Ansorge, J. (1980): Crustal structure under the central and eastern part of the Betic Cordillera. Geophysical Journal of the Royal Astronomical Society 63, 515-532. doi: 10.1111/j.1365-246X.1980. tb02635.x

Bousquet, J.C. (1979): Quaternary strike-slip faults in southern Spain. Tectonophysics 52, 277-286. doi: 10.1016/0040-1951(79)90232-4

Calmel-Avila, M. (2002): The Librilla "rambla" an example of morphogenetic crisis in the Holocene (Murcia, Spain). Quaternary International 93-94, 101-108.doi: 10.1016/S1040-6182(02)00009-5

Carta Arqueológica de la Región de Murcia:http://www.arqueomurcia. com/carta/ (last accessed April 2013).

De Larouzière, F.D., Bolze, J., Bordet, P., Hernández, J., Montenat, C., Ott d'Estevou1, P. (1988): The Betic segment of the lithospheric Trans-Alboran shear zone during the Late Miocene. Tectonophysics 152, 41-52. doi: 10.1016/0040-1951(88)90028-5

DeMets, C., R. G. Gordon, R.G., Argus, D.F., Stein, S. (1990): Current plate motions. Geophysical Journal International 101, 425-478. doi: 10.1111/j.1365-246X.1990.tb06579.x

Dewey, J.F., Helman, M.L., Turco, E., Hutton, D.H.W., Knott, S.D. (1989): Kinematics of the western Mediterranean. In: Coward, M.P., Dietrich, D., Park, R.G. (eds.): Alpine Tectonics. Geological Society, London, Special Publication, 265-283. doi: 10.1144/GSL. SP.1989.045.01.15

Echeverria, A., Khazaradze, G., Garate, J., Asensio, A., Masana, E., Suriñach, E. (2011): Present-day GPS crustal deformation rates in the Eastern Betics (SE Spain). Geophysical Research Abstracts 13 (EGU2011-8005), 1.

Egeler, C.G., Simon, O.J. (1969): Orogenic evolution of the Betic Zone (Betic Cordilleras, Spain), with emphasis on the nappe structures. Geologie en Mijnbouw 48, 296-305.

García-Mayordomo, J. (2005): Caracterización y Análisis de la Peligrosidad Sísmica en el Sureste de España. Ph.D. Tesis, Universidad Complutense de Madrid, Spain, 373 pp.

García-Mayordomo, J., Álvarez-Gómez, J.A. (2006): Estimación del terremoto máximo posible y su intervalo de recurrencia en la Falla de Carrascoy (Murcia) para su implementación en el cálculo de la peligrosidad sísmica de la región, Geogaceta 39, 51-54.

García-Mayordomo, J., Martínez-Díaz, J.J. (2006): Caracterización sísmica del Anticlinorio del Bajo Segura (Alicante): Fallas del Bajo Segura, Torrevieja y San Miguel de Salinas, Geogaceta 40, 19-22.

García-Mayordomo, J., Gaspar-Escribano, J.M., Benito, B. (2007a): Seismic hazard assessment of the Province of Murcia (SE Spain): analysis of source contribution to hazard. Journal of Seismology 11(4). doi: 10.1007/s10950-007-9064-0

García-Mayordomo, J. (2007b): Incorporación de datos y criterios geológicos en el análisis de la peligrosidad sísmica en regiones de actividad moderada: I. Definición y caracterización de fuentes sismogenéticas. Geogaceta 41, 87-90.

García-Mayordomo, J. (2007c): Incorporación de datos y criterios geológicos en el análisis de la peligrosidad sísmica en regiones de actividad moderada: II. Función de atenuación del movimiento del suelo y cálculo probabilístico. Geogaceta 42, 31-34.

García-Mayordomo, J., Insua-Arévalo, J.M., Martínez-Díaz, J.J., Jiménez-Díaz, A., Martín-Banda, R., Martín-Alfageme, S., Álvarez-Gómez, J.A., Rodríguez-Peces, M.A., Pérez-López, R., Rodríguez-Pascua, M.A., Masana, E., Perea, H., Martín-González, F., Giner-Robles, J., Nemser, E.S., Cabral, J., QAFI Compilers Working Group (2012): The Quaternary Active Faults Database of Iberia (QAFI v.2.0). Journal of Iberian Geology 38(1), 285-302. doi: 10.5209/rev_JIGE.2012. 
v38.n1.39219

Gauyau, F., Bayer, R., Bousquet, J.C., Lachaud, J.C., Lesquer, A., Montenat, C. (1977): Le prolongament de l'accident d'Alhama de Murcia entre Murcia et Alicante (Espagne méridionale). Bulletin de la Sociètè Géologique de France 7(3), 623-629.

Goodfriend, G.A., Stipp, J.J. (1983): Limestone and the problem of radiocarbon dating of land-snail shell carbonate. Geology 11, 575-577. doi:10.1130/0091-7613(1983)11<575:LATPOR >2.0.CO;2

Gràcia, E., Pallàs, R., Soto, J.I., Comas, M., Moreno, X., Masana, E., Santanach, P., Diez, S., Garcia, M., Dañobeitia, J.J., Bartolomé, R., Farrán, M., Gómez, M., Alpiste, M.J.R., Lastras, G., Wilmott, V., Perea, H., Blondel, P., Gómez, O., Bullock, L., Jacobs, C., Rouse, I., White, D., Whittle, S., Terrinha, P., Gafeira, J., Roque, C. (2006): Active Faulting offshore SE Spain (Alboran Sea): Implications for Earthquake Hazard Assessment in the South Iberian Margin. Earth and Planetary Science Letters 241(3-4), 734-749. doi:10.1016/j. eps1.2005.11.00IGME (2012): QAFI: Quaternary Active Faults Database of Iberia. Accessed March 2013, from IGME web site: http:// www.igme.es/infoigme/aplicaciones/QAFI/

Instituto Geográfico Nacional (IGN) (2013): National Seismic Catalogue. Madrid, Spain, www.ign.es. (last accessed April 2013).

Insua-Arévalo, J.M., García-Mayordomo, J., Salazar, A., RodríguezEscudero, E., Martínez- Díaz, J.J., Álvarez-Gómez, J.A., Canora, C., Martín-Banda, R., Pérez-López, R., Rodríguez- Pascua, M.A. (2012): Actividad holocena y pleistocena de la falla de Carrascoy, Murcia. Resultados preliminares de un análisis paleosísmico. Geotemas 13, 1511-1514.

Khazaradze, G., J. Gárate, E. Suriñach, J.M. Davila, E. Asensio (2008): Crustal deformation in south-eastern Betics from CuaTeNeo GPS network. Geotemas 10, 1-4.

Leyva Cabello, F., Silva Barroso, P.G., García Tortosa, F.J. (2010): Cartografía Geológica de la hoja 954 Totana, Mapa Geológico Digital de España E. 1:50.000. Instituto Geológico y Minero de España, Madrid, España.

Livermore, R.A., Smith, A.G. (1985): Some boundary conditions for the evolution of the Mediterranean Region. In: Stanley, D.J., Wezel, F.C. (eds.), Geological evolution of the Mediterranean Basin, Springer, New York, 83-98.

Martín-Banda, R., García-Mayordomo, J., Insua-Arévalo, J.M., Salazar-Rincón, A.E., Rodríguez-Escudero, E., Álvarez-Gómez, J.A., Martínez-Díaz, J.J., Medialdea, A., Herrero, M.J. (2014): Potencial sismogénico del segmento SO de la Falla de Carrascoy, Cordillera Bética (SE de España). In: Álvarez-Gómez, J.A., Martín González, F. (eds.), Resúmenes de la $2^{a}$ Reunión Ibérica sobre Fallas Activas y Paleosismología, Lorca, España, 31-34.

Martínez del Olmo, W., Klimowitz, J., Hernández, E. (2006): El despegue extensional mioceno de la zona de falla de Alhama de Murcia. Boletín Geológico y Minero 117 (3), 363-377.

Martínez-Díaz, J.J., Bejar-Pizarro, M., Álvarez-Gómez, J.A., Mancilla, F., Stich, D., Herrera, G., Morales, J. (2012a): Tectonic and seismic implications of an intersegment rupture. The damaging May 11th 2011 Mw 5.2 Lorca, Spain, earthquake. Tectonophysics 546-547, 2837. doi:10.1016/j.tecto.2012.04.010.

Martínez-Díaz, J.J., Masana, E., Ortuño, M. (2012b): Active tectonics of the Alhama de Murcia Fault, Betic Cordillera, Spain. Journal of Iberian Geology 38(1), 253-270. doi: doi:10.5209/rev_JIGE.2012. v38.n1.39218

Masana, E., Martínez-Díaz, J.J., Hernández-Enrile, J.L., Santanach, P. (2004): The Alhama de Murcia Fault (SE Spain), a seismogenic fault in a diffuse plate boundary: seismotectonic implications for the IberoMagrebian region. Journal of Geophysical Research 109, 1-17. doi: 10.1029/2002JB002359.

McClusky, S., Reilinger, R., Mahmoud, S., Ben-Sari, D., Tealeb, A. (2003): GPS constraints on Africa (Nubia) and Arabia plate motion.
Geophysical Journal International 155, 126-138. doi: 10.1046/j.1365246X.2003.02023.X.

Montenat, C., Ott d'Estevou, P., Coppier, G. (1990): Les bassins neógènes entre Alicante et Cartagena. Doc. et Trav. IGAL 12-13, 313-368.

Nocquet, J.M. (2012): Present-day kinematics of the Mediterranean: A comprehensive overview of GPS results. Tectonophysics 579, 220242. doi: 10.1016/j.tecto.2012.03.037

Ortuño, M., Masana, E., García-Meléndez, E., Martínez-Díaz, J.J., Štěpančíková, P., Cunha, P., Sohbati, R., Canora, C., Buylaert, J.P., Murray, A.S. (2012): An exceptionally long paleoseismic record of a slow-moving fault: The Alhama de Murcia Fault (Eastern Betic Shear Zone, Spain). Geological Society of America Bulletin 124(9-10), 1474-1494. doi: 10.1130/B30558.1

Perea, H., Gràcia, E., Alfaro, P., Bartolomé, R., Lo Iacono, C., Moreno, X., Masana, E., EVENT-SHELF Team (2012): Structure and potential seismogenic sources of the offshore Bajo Segura basin (SE Iberian Peninsula, Mediterranean Sea). Natural Hazards and Earth System Sciences 12, 3151-3168. doi: 10.5194/nhess-12-3151-2012

Pigati, J.S., J. A. Rech, J.A., J. C. Nekola, J. C. (2010): Radiocarbon dating of small terrestrial shells in North America. Quaternary Geochronology 5, 519-532. doi:10.1016/j.quageo.2010.01.001

Reicherter, K., Hübscher, C. (2007): Evidence for a seafloor rupture of the Carboneras Fault Zone (southern Spain): Relation to the 1522 Almería earthquake? Journal of Seismology 11, 15-26. doi: 10.1007/ s10950-006-9024-0

Sanz de Galdeano, C. (1990): Geologic evolution of the Betic Cordilleras in the Western Mediterranean, Miocene to the present. Tectonophysics 172, 107-119. . doi: 10.1016/0040-1951(90)90062-D.

Sanz de Galdeano, C., López-Garrido, A.C., García-Tortosa, F.J. (1998): Nuevos datos para la estimación de los valores de levantamiento desde el Tortoniense Superior a la actualidad en la parte centro-occidental de la Sierra de Carrascoy (provincia de Murcia). Geogaceta 23, 139- 142.

Serpelloni, E., Vannucci, G., Pondrelli, S., Argnani, A., Casula, G., Anzidei, M., Baldi, P., Gasperini, P. (2007): Kinematics of the western Africa-Eurasia plate boundary from focal mechanisms and GPS data. Geophysical Journal International 169(3), 1180-1200. doi: 10.1111/j.1365-246X.2007.03367.x

Scholz, C.H. (1992): The Mechanics of Earthquakes and Faulting. Cambridge University Press, Cambridge, 439 pp.

Silva, P.G. (1994): Evolución Geodinámica de la depresión del Guadalentín (Murcia) desde el Mioceno Superior hasta la actualidad: Neotectónica y Geomorfología. Ph.D. Tesis, Universidad Complutense de Madrid, Spain, 642 pp.

Silva, P.G., Goy, J.L., Somoza, L., Zazo, C., Bardají, T. (1993): Landscape response to strike-slip faulting linked to collisional settings: Quaternary tectonics and basin formation in the eastern Betics, Southeast Spain. Tectonophysics 224, 289-303. doi:10.1016/00401951(93)90034-H

Silva, P.G., Goy, J.L., Zazo, Lario, J., Bardají, T. (1997): Paleoseismic indications along "aseismic" fault segments in the Guadalentín depression (SE Spain). Journal of Geodynamics 24, 105-115. doi: 10.1016/S0264-3707(97)00011-2

Silva, P.G., Goy, J.L., Zazo, C., Bardaji, T. (2003): Fault-generated mountain fronts in southeast Spain: geomorphologic assessment of tectonic and seismic activity. Geomorphology 50, 203-225. doi:10.1016/S0169-555X(02)00215-5

Silva, P.G., Calmel-Avila, M., Bardaji, T., Goy, J.L., Zazo, C. (2008): Transition from alluvial to fluvial systems in the Guadalentin Depression (SE. Spain) during the Holocene. Lorca Fan versus Guadalentín River. Geomorphology 100, 144-153. doi:10.1016/j.geomorph.2007.10.023

Stirling, M.W., Goded, T., Berryman, K.R., Litchfield, N.J. (2013): Selection of earthquake scaling relationships for seismic hazard analy- 
sis. Bulletin of the Seismological Society of America 103(6), 29933011. doi: 10.1785/0120130052

Vissers, R.L.M., Meijninger, B.M.L. (2011): The 11 May 2011 earthquake at Lorca (SE Spain) viewed in a structural-tectonic context. Solid Earth 2, 199-204. doi:10.5194/se-2-199-2011

Weijermars, R. (1987): The Palomares brittle ductile shear zone of southern Spain. Journal of Structural Geology 9, 139-157. doi: 10.1016/0191-8141(87)90022-8
Wells, D.L., Coppersmith, K.J. (1994): New empirical relationships among magnitude, rupture length, rupture width, rupture area, and surface displacement. Bulletin of the Seismological Society of America 84, 974-1002.

Woodcock, N.H., Fischer, M. (1986): Strike-slip duplexes. Journal of Structural Geology 8(7), 725-735. doi: 10.1016/0191-8141(86)90021-0 